\title{
Summertime surface energy balance fluxes at two Beijing sites
}

Article

Accepted Version

Dou, J., Grimmond, S., Cheng, Z., Miao, S., Feng, D. and Liao, M. (2019) Summertime surface energy balance fluxes at two Beijing sites. International Journal of Climatology, 39 (5). pp. 2793-2810. ISSN 08998418 doi:

https://doi.org/10.1002/joc.5989 Available at https://centaur.reading.ac.uk/81499/

It is advisable to refer to the publisher's version if you intend to cite from the work. See Guidance on citing.

To link to this article DOI: http://dx.doi.org/10.1002/joc.5989

Publisher: Royal Meteorological Society

All outputs in CentAUR are protected by Intellectual Property Rights law, including copyright law. Copyright and IPR is retained by the creators or other copyright holders. Terms and conditions for use of this material are defined in the End User Agreement.

\section{www.reading.ac.uk/centaur}

\section{CentAUR}

Central Archive at the University of Reading 
Reading's research outputs online 
Dou JX, CSB Grimmond, Z Cheng, S Miao, D Feng, M Liao Summertime surface energy balance fluxes at two Beijing sites, International Journal of Climatology doi:10.1002/joc.5989

Summertime surface energy balance fluxes at two Beijing sites

Junxia Dou ${ }^{1 *}$, C. S. B. Grimmond ${ }^{2}$, Zhigang Cheng ${ }^{1}$, Shiguang Miao ${ }^{1}$, Dongying Feng ${ }^{3}$, Mingshui Liao ${ }^{3}$

${ }^{1}$ Institute of Urban Meteorology, China Meteorological Administration, China

${ }^{2}$ Department of Meteorology, University of Reading, UK

${ }^{3}$ Miyun Meteorological station, Beijing Meteorological Bureau, China

*jxdou@ium.cn, Institute of Urban Meteorology, CMA, No. 55 Beiwaxili Road, Haidian District, Beijing, P.R. China 100089 , T: 86 10 6840 0746

\begin{abstract}
Summertime (June to August 2015) radiative and turbulent heat fluxes were measured concurrently at two sites (urban and suburban) in Beijing. The urban site has slightly lower incoming and outgoing shortwave radiation, lower atmospheric transmissivity and a lower surface albedo compared to the suburban site. Both sites receive similar incoming longwave radiation. Although the suburban site had larger daytime outgoing longwave radiation $\left(L_{\uparrow}\right)$, differences in the daily mean $L_{\uparrow}$ values are small, as the urban site has higher nocturnal $L_{\uparrow}$. Overall, both the midday and daily mean net all-wave radiation $\left(Q^{*}\right)$ for the two sites are nearly equal. However, there are significant differences between the sites in the surface energy partitioning. The urban site has smaller turbulent sensible heat $\left(Q_{H}\right)\left(21-25 \%\right.$ of $Q^{*}$ (midday - daily)) and latent heat $\left(Q_{E}\right)$ fluxes (21-45\% of $Q^{*}$ ). Whereas, the suburban proportions of $Q^{*}$ are $Q_{H} 32-32 \%$ and $Q_{E} 39-66 \%$. The daily (midday) mean Bowen ratio $\left(Q_{H} / Q_{E}\right)$ was 0.56 and $0.49(0.98$ and 0.83$)$ for the urban and suburban sites, respectively. These values are low compared to other urban and suburban areas with similar or larger fractions of vegetated cover. Likely these are caused by the widespread external water use for road cleaning/wetting, greenbelts, and air conditioners. Our suburban site has quite different land cover to most previous suburban studies as crop irrigation supplements rainfall. These results are important in enhancing our understanding of surface-atmosphere energy exchanges in Chinese cities, and can aid the development and evaluation of urban climate models and inform urban planning strategies in the context of rapid global urbanization and climate change.
\end{abstract}

Key words: radiative fluxes; turbulent heat flux; Bowen ratio; external water; Beijing

\title{
1. Introduction
}

Although the increasingly urbanized world population live mostly in medium and smaller cities, $13 \%$ are concentrated in just 28 megacities (i.e. population $>10$ million) (UN-Habitat, 2016). One of these, Beijing, already had a permanent population exceeding 21 million in 2016 (Beijing Municipal Bureau of Statistics, 2017). One feature of urbanization is the replacement of natural surfaces with impervious materials (roads, buildings, pavements) and dense buildings. These changes affect the surface energy balance and the boundary layer structure, resulting in well-known urban climate effects, such as the urban heat island, degradation of air quality and enhanced heat waves and flooding (UN-Habitat, 2016). Thus, it is critical to understand the exchanges of heat, mass, and momentum between the atmosphere and the urban surface to inform urban development and design (Grimmond et al., 2004) and to evaluate strategies to mitigate inadvertent effects, such as heat stress (Zhang et al., 2015). This is particularly important in megacities in China where data on these surface energy balance exchanges, the development of parameterizations, and the evaluation and application of numerical models are still all limited.

Knowledge of the surface energy balance (SEB) is fundamental to the understanding of the boundary layer meteorology and climatology of any site (Oke, 1988; Roth, 2000; Raupach, 2001). The eddy covariance (EC) method allows direct measurement of atmospheric heat and water vapour transport in the boundary layer. Despite the practical difficulties in observing and interpreting the energy balance of an urban area, a relatively large number of urban flux campaigns around the world using the EC method have been undertaken. Earlier research focused largely on cities in North America (Grimmond and Oke, 1995). This was followed by many turbulent flux observations in European cities, such as Basel, Switzerland (Christen and Vogt, 2004; Rotach et al., 2005), Marseille, France (Grimmond et al., 2004), Łódź, Poland (Offerle et al., 2006a, 2006b), Helsinki, Finland (Vesala et al., 2008), Essen, Germany (Weber and Kordowski, 2010), Oberhausen, Germany (Goldbach and Kuttler, 2012), Swindon, UK (Ward et al., 2013) and London, UK (Kotthaus and Grimmond, 2014a). Observations in other climates and synoptic conditions, include: Christchurch, New Zealand (Spronken-Smith, 2002); Tokyo, Japan (Moriwaki and Kanda, 2004); Melbourne, Australia (Coutts et al., 2007); Cairo, Egypt (Frey et al., 2011); Montreal, Canada (Bergeron and Strachan, 2012); Telok Kurau, Singapore (Roth et al, 2017). Observations in Chinese cities include sites in the central business area of Nanjing (Peng et al., 2008) and Shanghai (Ao et al., 2016a), and in a densely built-up commercial and residential area of Beijing (Liu et al., 2012; Miao et al., 2012 , Wang et al. 2015) and in Tianjin (Huang et al., 2011). 
Most studies report data for a single site, with concurrent measurements over different urban areas (city centre, residential etc) scarce (exceptions include the studies cited above in Basel, Łódź, Essen, Montreal, and Oberhausen; and in China: in and around (urban, suburban, grassland and farmland) Nanjing (Guo et al., 2016) and Beijing (Wang et al., 2015). In this study, simultaneously observed summer-time urban surface energy balance fluxes are reported for an urban (IAP) and suburban (MY) site in Beijing (Figure 1a) for 92 summer days in 2015.

Previous SEB studies at IAP (Miao et al., 2012) observed unexpectedly small summer mean Bowen ratios compared to those observed at urban sites with larger fractions of vegetated cover. As this earlier study did not explore this, here we use the two contrasting sites (IAP and MY) to determine if these small values are observed again and to consider the impact of site characteristics, environmental factors and human behaviour on the energy partitioning.

\section{Methods}

\subsection{Site description}

The energy balance flux measurements for both the urban and suburban sites in Beijing (Figure 1) are analyzed for the period 1 June (DoY (Day of Year): 152) to 31 August (DoY: 243) 2015. The two sites are $70 \mathrm{~km}$ apart, with an elevation difference of $29 \mathrm{~m}$ (IAP $49 \mathrm{~m}$ above sea level (asl), MY $78 \mathrm{~m}$ asl).

The urban site is centred on the 325 m Institute of Atmospheric Physics (IAP) Chinese Academy Sciences tower in northwestern Beijing city (Figure 1). It is surrounded by residential, commercial (i.e. hotels, restaurants, supermarket, shopping mall, offices), and institutional (i.e. university, hospital) buildings (Table 1). Most buildings in the area are 15-30 m, with a mean height of 25.5

$\mathrm{m}$. The tallest building in the area is $104 \mathrm{~m}$, to the southwest ( $\sim 100 \mathrm{~m}$ from tower) and south (within $300 \mathrm{~m})$ there are several very tall buildings $(65-75 \mathrm{~m})$, and to the north, northwest and southeast within $500 \mathrm{~m}$ of the tower there are buildings over $50 \mathrm{~m}$ tall (Figure 1b,d). This mix of buildings and clusters of much taller buildings is typical of Beijing, many urban areas in China and cities elsewhere.

Using the Stewart and Oke (2012) Local Climate Zone (LCZ) system, the area can be characterized as 'Compact High-rise' (LCZ1) and 'Compact Midrise' (LCZ2). There are numerous roads in the area, with the closest road (Beitucheng Road) $50 \mathrm{~m}$ north of the tower, with the $3^{\text {rd }}$ Ring Road about $800 \mathrm{~m}$ south and the $4^{\text {th }}$ Ring Road $1.2 \mathrm{~km}$ to the north (Figure $1 \mathrm{~b}$, d). The Beijing-Tibet Expressway and Beichen West Road (running north - south) are $300 \mathrm{~m}$ and $900 \mathrm{~m}$ east of the tower, respectively. To the west, North Taipingzhuang Road and Huayuan Road are $600 \mathrm{~m}$ and $800 \mathrm{~m}$ from tower, respectively. The largest vegetated areas are a narrow east-west band of deciduous trees (10-20 m tall) and lawns within the Yuan Dynasty Capital City Wall Relics Park.

The suburban site, Miyun Meteorological Station (MY), is about $70 \mathrm{~km}$ northeast of IAP (Figure 1a, Table 1). The surroundings of the instrument tower include mixed vegetation (wheat/maize rotation farmland, orchard, vegetable plots, grass lawn) and buildings (residential, office) (Figure 1c, e). The residential buildings (6 floors, 18-21 m) are to the west (from $170 \mathrm{~m}$ ), northwest (>200 m) and north $(>70 \mathrm{~m}$ ) of the tower. Office buildings (two of the Miyun Meteorological Station and one of the Miyun Hospital) are located only $10 \mathrm{~m}$ and $30 \mathrm{~m}$ north, and $400 \mathrm{~m}$ south of the tower, with a significant difference in mean height $(8,10.5 \mathrm{and} 55 \mathrm{~m}$, respectively). A large agriculture area is primarily $>350 \mathrm{~m}$ southeast of the flux tower. This mix of buildings and agriculture is common in the suburbs of Chinese cities. There are only two roads within a 500 m radius: the east-west Migu Road and northsouth Tanxi Road, located $170 \mathrm{~m}$ south and $420 \mathrm{~m}$ west of the tower, respectively.

\subsection{Instruments and data processing}

At both sites the turbulent sensible and latent heat and carbon dioxide fluxes are measured using fast response eddy covariance (EC) sensors. These consist of a three-dimensional sonic anemometer-thermometer (Campbell Scientific Inc., USA) and an openpath infrared gas analyzer (LI-7500, LI-COR, Inc., USA) to measure the mean and fluctuating quantities of wind speed and virtual temperature, $\mathrm{CO}_{2}$ and $\mathrm{H}_{2} \mathrm{O}$ vapour, respectively. The LI-7500 is calibrated twice a year (April, November) using a two-point calibration with nitrogen and $450 \mathrm{ppm} \mathrm{CO}_{2}$ and using a dew point generator for moisture. 
To ensure the instruments are above the roughness sub-layer (RSL), within the inertial sub-layer (ISL) or constant flux layer, the instruments are mounted at $140 \mathrm{~m}$ (IAP) and $36 \mathrm{~m}$ (MY) above ground level. Individual tall buildings have a large influence and increase the depth of the roughness sub-layer (RSL) (Millward-Hopkins et al., 2011; Kanda et al., 2013; Kent et al., 2017; Hertwig et al., 2018). Analyses suggests the urban canopy layer at the IAP site is approximately 47-63 m thick (Peng and Hu, 2006) with turbulent variances at 47, 140 and $280 \mathrm{~m}$ levels confirming $47 \mathrm{~m}$ is within the RSL, while 140 and $280 \mathrm{~m}$ are within constant flux layer (Zou et al., 2011).

The instruments are oriented into the predominant wind direction at each site to reduce flow distortion from both the instruments and the towers themselves. At IAP the instruments are mounted on a $325 \mathrm{~m}$ tower at the end of a $2.5 \mathrm{~m}$ boom facing toward the southeast. The instrument height of $140 \mathrm{~m}$ has been demonstrated to be well above the RSL based on boundary layer wind structure analyses (Peng and Hu, 2006; Miao et al., 2012). At MY, the instruments are mounted at the end of a $2 \mathrm{~m}$ boom oriented to the east on a $38 \mathrm{~m}$ tall tower.

The EC systems are sampled at $10 \mathrm{~Hz}$ using CR5000 (IAP) and CR3000 (MY) data-loggers (Campbell Scientific Inc, USA) with post-processing to report 30 min statistics and fluxes (Aubinet et al., 2000). Flux data are processed with EddyPro Advanced (v6.1.0 beta, LI-COR) following standard procedures (Moncrieff et al., 1997) including de-spiking of raw data, correction for angle of attack, time-lag compensation by seeking maximum covariance, double coordinate rotation, correction of sonic temperature for humidity, high- and low-frequency spectral corrections, Webb et al. (1980) density corrections, and physically reasonable thresholds are applied. No friction velocity screening is used, as $u_{*}$ values $<0.1 \mathrm{~m} \mathrm{~s}^{-1}$ are rare in the datasets. Only the 30 -min periods with a quality flag of " 0 " (i.e. best quality data) (LI-COR, 2017) are analysed (of the 4416 potential periods) there are: at IAP - $1325 Q_{H}, 1149 Q_{E}$ and $1502 \mathrm{CO}_{2}$ flux periods; and, at MY $1016 Q_{H}, 858$ of $Q_{E}$ and $813 \mathrm{CO}_{2}$ periods. Rainfall is the cause of a large amount of data loss at both sites. Only observed data are analysed, therefore when all variables in a period are needed (e.g. $24 \mathrm{~h}$ ) the period with available data is used to derive the statistics (e.g. mean) prior to calculating derived terms (e.g. storage heat flux, Bowen ratio etc).

Kipp \& Zonen (Netherlands) four-component unventilated radiometers [CNR1 (at IAP) and CNR4 (at MY)] provide the incoming and outgoing longwave $\left(L_{\downarrow}\right.$ and $\left.L_{\uparrow}\right)$ and shortwave $\left(K_{\downarrow}\right.$ and $\left.K_{\uparrow}\right)$ radiation and net all-wave radiation $\left(Q^{*}\right)$ fluxes. At IAP and MY, the radiometers point south at the same height as the EC instruments. The instruments are logged on the same datalogger as the EC instruments.

On the MY tower four levels $(10.0,17.2,24.2,36.0 \mathrm{~m})$ of air temperature and relative humidity (HMP45C, Vaisala, Finland) and wind speed (010C, Met One Instruments Inc, USA); and two levels (10.0, $36.0 \mathrm{~m}$ ) of wind direction (020C, Met One Instruments Inc, USA) are measured.

Routine measurements by Miyun Meteorological Station (air temperature, precipitation and visibility) and by IAP (air temperature; HMP45C, Vaisala, Finland; precipitation data TE525, Campbell Scientific Inc, USA) at a surface station about $20 \mathrm{~m}$ west of the IAP tower are used. Visibility data are supplied by the Haidian (HD) Meteorological Station about $8 \mathrm{~km}$ west of the IAP tower. At MY gravimetric soil moisture content is measured at 5 consecutive $0.1 \mathrm{~m}$ levels in irrigated cropland and at 10 levels in natural farmland every 10 days within the $300 \mathrm{~m}$ of the site.

To aid interpretation of the radiative fluxes, hourly $\mathrm{PM}_{2.5}$ data observed at Baolian (BL) (10 km southwest of IAP tower) and Shangdianzi (SDZ) (40 km northeast of MY tower) (Figure 1a) are used. These are assumed to be representative of urban and suburban Beijing (Zhao et al. 2009; Zhao et al. 2013).

Storage heat flux values can be determined as an observational residual of the urban energy balance but this compounds all the measurement uncertainties into this term. Notably here both anthropogenic heat flux $\left(Q_{F}\right)$ and advection are not directly determined and are potentially important terms.

Here $Q_{F}$ is calculated by using the LQF version (Gabey et al., 2018, Lindberg et al., 2018) of the LUCY model (Allen et al., 
2011; Lindberg et al., 2013). Assumptions made in this application are: mean vehicle speed of $48 \mathrm{~h}^{-1}$ and the fraction of vehicles on the road is 0.8. The data sources are: Beijing Yearbook (Beijing Municipal Bureau of Statistics, 2016) for number of vehicles (freight, cars and motorcycles), Gridded Population of the World (GPWv4) (CIESIN, 2016) for population density in the IAP area, Beijing Miyun Statistical Yearbook (Statistics Bureau of Miyun District, 2016) for MY population density and Beijing Yearbook (Beijing Municipal Bureau of Statistics, 2016) for the energy consumption data for 2015.

Following Best and Grimmond (2015) the sum of the errors, from the directly measured terms (i.e., $Q^{*}, Q_{H}$ and $Q_{E}$ ), would be $23 \%$ during the day and double that at night. These are minima, given the other terms, so we refer to this flux as $Q_{r e s}$.

\subsection{Footprint analyses}

The Kljun et al. (2004) footprint model is used to determine the probable source area of the turbulent fluxes at both study sites. The footprint function estimates the location and relative importance of passive scalar sources influencing flux measurements at a given receptor height, depending on receptor height, atmospheric stability, and surface roughness (Kljun et al. 2004).

To determine the source areas roughness length for momentum $\left(z_{0}\right)$ and zero plane displacement height $\left(z_{d}\right)$ are needed. Using the rule of thumb (Grimmond and Oke, 1999a) and the mean building height $\left(z_{\mathrm{H}}\right)$ of $19.1 \mathrm{~m}$ within $4 \mathrm{~km} \times 4 \mathrm{~km}(\mathrm{Miao}$ et al., 2012)

$z_{d}$ is estimated to be $12.8 \mathrm{~m}\left(0.67 z_{\mathrm{H}}\right)$ and $z_{0}$ is $2.9 \mathrm{~m}\left(0.15 z_{\mathrm{H}}\right)$. Previous micrometeorological estimates at the IAP site found $z_{0}$ to be $>3 \mathrm{~m}$ (Yin and Hong, 1999; Li et al., 2003; Al-Jiboori and Hu, 2005). Grimmond and Oke (1999a) suggest a realistic range of $z_{0}$ for city core with a mixture of low- and high-rise buildings may be about $0.1 z_{\mathrm{H}}-0.2 z_{\mathrm{H}}$. Kent et al. (2017) suggest $z_{d}$ may be twice this size (2RT). Using Kanda et al. (2013) and eight sectors of $500 \mathrm{~m}$ these $\left(z_{0}\right.$ and $\left.z_{d}\right)$ vary between 0.6 and $13.6 \mathrm{~m}$, and from 14 to $69 \mathrm{~m}$ respectively. At MY, $z_{0}(2.9 \mathrm{~m})$ and $z_{d}(4.1 \mathrm{~m})$ are calculated from neutral profile measurements with the logarithm law and Newton iteration (Zhao et al., 2004). Thus, some uncertainty in the probable turbulent flux sources area dimensions are introduced from these but through iteration the impact of these values become insignificant (Kent et al. 2017).

The atmospheric stability parameter $(\zeta)$ :

$$
\zeta=\left(\mathrm{z}-z_{d}\right) / \mathrm{L} \quad(1)
$$

is a function of Obukhov length $(\mathrm{L})$ obtained from the $\mathrm{EC}$ observations. Here we classify unstable as $\zeta<-0.1$, neutral $|\zeta| \leq 0.1$ and stable conditions $\zeta>0.1$ using the $z_{d}$ of $12.8 \mathrm{~m}$. At IAP and MY, conditions were predominantly unstable (60\% and 59\%), with $12 \%$ and $22 \%$ neutral, and $28 \%$ and $19 \%$ stable, respectively. The extent of the $90 \%$ of source area is used in subsequent analyses (Figure 2).

At IAP, the probable $90 \%$ source area extent is on average about $1640 \mathrm{~m}$ from the tower, extending on average to about $1850 \mathrm{~m}$ to the northeast $\left(0-30^{\circ}\right)$ and northwest $\left(270-300^{\circ}\right)$ and $1430 \mathrm{~m}$ to the east (Figure 2a). However, given the use of constant roughness parameters with direction, the extent may actually be more variable and smaller. The probable extent at the MY site is on average about $460 \mathrm{~m}$ from the tower, extending to about $500 \mathrm{~m}$ in the north and only about $400 \mathrm{~m}$ in the southeast (Figure $2 \mathrm{~b}$ ).

Following Schmid et al. (1991), the 90\% radiometer source area radii are calculated as 420 and $108 \mathrm{~m}$ from the IAP and MY towers, respectively. The overall source area characteristics of both sites are presented in Table 2 .

As others have found (e.g. Christen and Vogt, 2004; Offerle et al., 2006b), the radiometer and turbulent fluxes source areas differ slightly in location and surface characteristic at both IAP and MY (Table 2). However, the net all-wave radiation fluxes $\left(Q^{*}\right)$ are very similar, especially daily, at the IAP and MY sites (section 3.2) as there are compensating effects between radiation balance fluxes (Oke et al., 2017). Thus, ratios of turbulent heat fluxes to $Q^{*}$ can be compared between the sites.

\subsection{Classification of sky conditions}

Using a bulk daily shortwave transmission $\left(\tau_{\text {day }}\right)$ calculated from the daily total downward shortwave radiation at the measurement height $\left(K_{\downarrow, \text { day }}\right)$ and daily total solar irradiance at the top of the atmosphere $\left(G_{0}\right)$ :

$$
\tau_{\text {day }}=K_{\downarrow, \text { day }} / G_{0}
$$

where Go is calculated following Ao et al. (2016b), days are classified as clear, overcast, and rainy. If any rain occurred the day is defined as rainy. If $\tau_{\text {day }}>0.50$, and both the daily mean visibility and $>75 \%$ of the hourly visibility values within the day are $>$ 
Dou JX, CSB Grimmond, Z Cheng, S Miao, D Feng, M Liao Summertime surface energy balance fluxes at two Beijing sites, International Journal of Climatology doi:10.1002/joc.5989

$10 \mathrm{~km}$, the day is "clear". All remaining days are classified as "overcast". The $\tau_{\text {day }}>0.50$ threshold follows Kawai and Kanda (2010a), who define clear skies as having a total diffuse to downward shortwave radiation ratio (DDR) of less than 0.50 , and Duffie and Beckman (2013) who indicate when DDR $=0.50 \tau$ is about 0.50 (Figure 2.11.1 in Duffie and Beckman, 2013).

In the analysis period there are 23 clear, 27 overcast and 42 rainy days at IAP, whereas for MY there are 19 clear, 37 overcast and 36 rainy days. Despite the small differences (e.g. more clear and rainy days at IAP, more overcast days at MY), both sites experience effectively the same weather conditions. Both have the same 14 clear, 20 overcast and 31 rainy days during the 92 days measurement period. When both sites had clear days $\tau_{\text {day }}>0.65$.

\section{Results and discussion}

\subsection{Meteorological conditions during the study period}

At IAP the daily mean $2-\mathrm{m}$ air temperature varied from 21.0 to $32.2^{\circ} \mathrm{C}$, with monthly means of $24.7,26.5$ and $26.7^{\circ} \mathrm{C}$ for June, July and August, respectively. The overall summer mean was $26.0^{\circ} \mathrm{C}$ (Figure 3a). At MY, the daily mean 2-m air temperatures were generally cooler $\left(18.8\right.$ to $\left.31.5^{\circ} \mathrm{C}\right)$ with a summer mean of $24.7^{\circ} \mathrm{C}$. These were very similar to Normal (1981-2010) with the latter only $0.1^{\circ} \mathrm{C}$ less, July $\left(25.8^{\circ} \mathrm{C}\right)$ the same, June $\left(23.4^{\circ} \mathrm{C}\right)$ and August $\left(24.8^{\circ} \mathrm{C}\right) 0.6^{\circ} \mathrm{C}$ cooler and $0.3^{\circ} \mathrm{C}$ warmer than the Normal, respectively.

The IAP total rain $(304.6 \mathrm{~mm})$ consisted of 86.9, 149.0 and $68.7 \mathrm{~mm}$ in June, July and August, respectively. Periods of no rain (e.g. 5-11 July) were followed with rain (e.g. $97.7 \mathrm{~mm}$ in 10 days 14-23 July). In August 87\% of the monthly total occurred in two days (1st and 7th August, 15.5 and $44.5 \mathrm{~mm}$, respectively), with the rest occurring on five days. This left two rain-free periods (918 August, 24-29 August).

Overall MY was wetter $(375.4 \mathrm{~mm})$ than IAP $(304.6 \mathrm{~mm})$ but June $(66.0 \mathrm{~mm})$ was drier, with rain on only 2 days between 20 to 30 June, and none in the first six days of the month. July $(222.2 \mathrm{~mm})$ was wetter than the Normal (186.2 mm), despite a rain-free period from 5-14 July. The 9-18 August was rain free at MY (like IAP) resulting in August (87.2 mm) being very dry (50\% of the Normal, $176.1 \mathrm{~mm})$.

Overall, the study period air temperature did not differ significantly from typical summer conditions in the region, but precipitation was less than Normal, especially in August. The prevailing wind at IAP $(140 \mathrm{~m})$ was from the NE $\left(0-30^{\circ}\right)$ and SW $\left(180-240^{\circ}\right)$ (Figure 3b-d). While at MY, the winds were predominantly easterlies $\left(60-120^{\circ}\right)$, with daytime winds also common from the southwest $\left(210-270^{\circ}\right)$ because of terrain effects (Figure 3e-g).

\subsection{Surface radiation budget}

During this summer daily mean incoming shortwave radiation $\left(K_{\downarrow}\right)$ was slightly less at IAP than MY (difference $7.5 \mathrm{~W} \mathrm{~m}^{-2}$ ) (Figure 4a, b, Table 3). When the data are stratified by sky conditions (Section 2.4), it is evident that lower IAP $K_{\downarrow}$ values occur on days with higher atmospheric $\mathrm{PM}_{2.5}$ concentrations (not shown) at the urban site than the suburban site. Cloud and rain result in a reduction in $K_{\downarrow}$, as expected, with daily mean values under overcast and rainy sky conditions $68 \%$ and $49 \%$ that of clear days $\left(293.0 \mathrm{~W} \mathrm{~m}^{-2}\right)$ at IAP, and $71 \%$ and $53 \%$ of clear days $\left(297.5 \mathrm{~W} \mathrm{~m}^{-2}\right)$ at MY.

The bulk transmissivity $\tau$ under different sky conditions is used to assess the influence of cloud, rain and PM $\mathrm{PM}_{2.5}$ concentration on $K_{\downarrow}$ at both sites (Figure 5a-d). For clear days, most of the daytime $\tau$ values are greater than 0.60 after 9:00 (LST), with a midday median (10:00-14:00 LST) $\tau$ of 0.71 (IAP) and 0.73 (MY). Under overcast conditions, the maximum $\tau$ is never above 0.60 at either site, with the midday median $\tau$ decreasing to 0.52 (IAP) and 0.55 (MY). On rainy days, almost all $\tau$ values are lower than 0.40 . Therefore the midday median $\tau$ is smaller: IAP $(0.33)$ compared to MY $(0.35)$. Overall summer midday median $\tau$ values are 0.55 (IAP) and 0.59 (MY).

Midday median $\tau$ both for clear and overcast sky conditions are higher in Beijing than Shanghai (clear 0.64 and cloudy 0.49, Ao et al., 2016b). This may result from differences in atmospheric water vapour and/or concentration and composition of aerosols (Yao et al., 2002; Chan and Yao, 2008; Zhang and Cao, 2015; Ao et al., 2016b). As observed in Shanghai, $\tau$ values are smaller near sunrise than sunset at both sites in Beijing. This can probably be attributed to the longer atmospheric path having a frequent 
Dou JX, CSB Grimmond, Z Cheng, S Miao, D Feng, M Liao Summertime surface energy balance fluxes at two Beijing sites, International Journal of Climatology doi:10.1002/joc.5989

presence of nocturnal residual layers (Peng et al. 2017), which are dispersed by mixing later in the day (Ao et al., 2016b).

In terms of differences between the two Beijing sites, MY has a slightly higher $\tau$ than IAP before noon, while in the afternoon $\tau$ at both sites are nearly equal, or the $\tau$ values are a little smaller at MY than IAP with the exception of rainy days (Figure 5a-d). This is attributed to different diurnal patterns in $\mathrm{PM}_{2.5}$ concentrations between the two sites in Beijing. During the daytime, $\mathrm{PM}_{2.5}$ concentrations in the urban area reach their peak around noon, influenced by cooking and traffic; then decrease rapidly to a minima about 15:00 due to boundary layer growth. Whereas in the suburban area, the minima $\mathrm{PM}_{2.5}$ concentration generally occur in the morning that gradually increase until the evening associated with pollutant transport as the wind veers from northeasterly to southerly caused by local mountain-valley breezes (Zhao et al., 2009). Thus, diurnal and regional wind circulations which influence $\mathrm{PM}_{2.5}$ concentrations, influence local radiation exchanges and thus $\tau$ values at both sites.

Outgoing shortwave radiation $K_{\uparrow}$ is also lower at the urban site (Figure 4c, d), with summer daily averages of 23.2 and $27.5 \mathrm{~W} \mathrm{~m}^{-2}$ at IAP and MY, respectively (Table 3). As expected, the $K_{\uparrow}$ values decrease from clear to overcast to rainy days at both sites, with a daily mean value of $30.8,24.1$ and $17.2 \mathrm{~W} \mathrm{~m}^{-2}$ at IAP, and $38.8,28.2$ and $19.8 \mathrm{~W} \mathrm{~m}^{-2}$ at $\mathrm{MY}$, respectively.

The lower $K_{\uparrow}$ values at IAP are associated with lower albedo $(\alpha)$ at IAP than MY for all sky conditions (Figure 5e-h). Albedo differences between IAP and MY are greatest on clear days. The dominance of diffuse radiation on overcast days resulted in slightly higher albedos than on clear and rainy days at both sites, with a more obvious increase at IAP. Under rainy conditions, the surface is wet, hence the decrease in surface albedo (Ao et al., 2016b). The lowest albedo values occurred under rainy conditions, again as expected, at MY. However, at IAP daytime and midday median values of albedo for rainy days were still greater than for clear days. This might be explained by IAP having more and taller buildings, and thus a greater proportion of walls that do not get wet in the rain. Between-site differences in midday median values of albedo were always greater than differences in the daytime median values for any sky conditions, indicating that street canyons play an important role in radiation trapping when solar elevation angles are greater. Based on the summer average, the midday and daytime albedo were 0.10 and 0.11 at IAP, and they were both 0.13 at MY. These values are the same as observed for urban and suburban sites in Basel (Christen and Vogt, 2004), but lower than reported in other city centres [e.g., 0.16, 0.18 - Marseille (Grimmond et al., 2004); 0.14 KSK London (Kotthaus and Grimmond, 2014a, 2014b); 0.14 Shanghai (Ao et al., 2016b)] and suburban sites [e.g., 0.15 Łódź (Offerle et al., $2006 \mathrm{~b}$ ); 0.17 Miami (Newton et al., 2007); 0.24, 0.25- Kansas City (Balogun et al., 2009); 0.18 Oberhausen (Goldbach and Kuttler, 2012)].

Incoming longwave radiation $L_{\downarrow}$ is primarily influenced by the existence of cloud, boundary layer temperatures, water vapour and aerosol content (Flerchinger et al., 2009; Wang and Dickinson, 2013; Oke et al., 2017). As expected (e.g. Kotthaus and Grimmond, 2014a; Ao et al., 2016b), cloud cover enhances $L_{\downarrow}$ at the two sites (Figure 4e, f). The $L_{\downarrow}$ decreases from overcast to rainy to clear days at both sites, with a daily mean value of $408.4,407.5$ and $385.1 \mathrm{~W} \mathrm{~m}^{-2}$ at IAP, and $411.8,409.1$ and $386.2 \mathrm{~W}^{-}$ 2 at MY, respectively.

Generally, urban $L_{\downarrow}$ is larger than suburban or rural $L_{\downarrow}$ given the warmer urban boundary layer (Oke et al., 2017). However, $L_{\downarrow}$ is also enhanced by water vapour (Christen and Vogt, 2004). IAP-MY difference in $L_{\downarrow}$ are negative for all sky conditions, as the air near the IAP radiative sensor is drier (cf., clear $=7.7 \mathrm{~g} \mathrm{~kg}^{-1}$, overcast $=10.8 \mathrm{~g} \mathrm{~kg}^{-1}$ and rainy $=10.9 \mathrm{~g} \mathrm{~kg}^{-1}$ ) than at MY (clear $=12.5 \mathrm{~g} \mathrm{~kg}^{-1}$, overcast $=15.5 \mathrm{~g} \mathrm{~kg}^{-1}$ and rainy $=14.3 \mathrm{~g} \mathrm{~kg}^{-1}$ ). These results are similar to differences observed in $L_{\downarrow}$ between urban and rural sites in Basel (Christen and Vogt, 2004).

Although the suburban site has greater outgoing longwave radiation $\left(L_{\uparrow}\right)$ at midday and during the daytime, the difference in the daily mean $L_{\uparrow}$ values is very small, indicating that the urban site has a larger $L_{\uparrow}$ at night (Table 3, Figure 4e, f). During the daytime, the measured urban $L_{\uparrow}$ values are less than over the suburban surface, probably a result of the additional radiation trapping in street canyons in the more built up urban area. While the urban IAP site has higher $L_{\uparrow}$ for most of the night, indicating a higher surface temperature $\left(T_{s}\right)$ and/or differences in emissivity associated with the differences in urban form (e.g. reduced sky view factor (SVF) in the urban area) and materials. The greater radiative trapping at IAP maintains a warmer temperature than at the more open MY area. 
Dou JX, CSB Grimmond, Z Cheng, S Miao, D Feng, M Liao Summertime surface energy balance fluxes at two Beijing sites, International Journal of Climatology doi:10.1002/joc.5989

Overall, the IAP urban site has a very slightly smaller net radiation balance, $Q^{*}$, than at the MY suburban site. However, both the midday and daily mean net all-wave radiation $\left(Q^{*}\right)$ values of the two sites are nearly equal, with a midday and daily mean value of 455.0 and $126.3 \mathrm{~W} \mathrm{~m}^{-2}$ at IAP, and 455.7 and $129.9 \mathrm{~W} \mathrm{~m}^{-2}$ at MY, respectively (Table 3).

\subsection{Turbulent heat fluxes}

\subsubsection{Daily variation}

The diurnal course of the turbulent sensible heat fluxes $\left(Q_{H}\right)$ at IAP and MY have similar temporal patterns, but differ in magnitude (Figure 6). At both sites, the 30-min median $Q_{H}$ peaks in the early afternoon (13:30 at IAP, 14:30 at MY), with maximum values of $128 \mathrm{~W} \mathrm{~m}^{-2}$ (IAP) and $154 \mathrm{~W} \mathrm{~m}^{-2}$ (MY). The IAP values are similar to previous IAP data; for example, summer 2011 peak monthly-averaged diurnal values $\sim 100 \mathrm{~W} \mathrm{~m}^{-2}$ (Wang et al., 2015) and summer 2009-2010 peak values of $200 \mathrm{~W} \mathrm{~m}^{-2}$ on clear and $\sim 100 \mathrm{~W} \mathrm{~m}^{-2}$ on cloudy days (Miao et al., 2012).

Surprisingly, these maxima are lower at both sites than EC values observed previously in cities (cf. Figure 7a; urban range: 180$390 \mathrm{~W} \mathrm{~m}^{-2}$; suburban range: $\left.160-292 \mathrm{~W} \mathrm{~m}^{-2}\right)$. Areas with low vegetation cover $\left(\lambda_{v}\right)$ similar to IAP $\left(\lambda_{v}=19 \%\right)$, such as $\operatorname{Shanghai}$ $\left(\lambda_{v}=14 \%\right.$ ), have summer median daytime peak $Q_{H}$ values (Ao et al., 2016a) that are more than twice that at IAP (Figure 7a). The IAP $Q_{H}$ is also smaller than sites with more vegetation (e.g. Eódź CBD $\lambda_{v}=24 \%$; Basel U2 $\lambda_{v}=31 \%$ ). Some of this can be attributed to smaller plan area of buildings $\left(\lambda_{b}=24 \%\right)$ at IAP than Łódź (35\%) (Offerle et al., 2006b) or Basel (37\%, Christen and Vogt, 2004) (see section 3.3.2 for ratios).

Moreover, the IAP daytime $Q_{H}$ is $\sim 20 \%$ less than the MY flux. This urban-suburban difference is unlike patterns observed in other city comparisons, for example, in Basel (Christen and Vogt, 2004), Łódź (Offerle et al., 2006b), Essen (Weber and Kordowski, 2010) and Oberhausen (Goldbach and Kuttler, 2012). All have larger values at the urban sites, with summertime daytime/daily $Q_{H}$ differences of approximately 20-30\% compared to suburban sites.

Previous urban studies have reported both positive and negative nocturnal $Q_{H}$ fluxes (Christen and Vogt, 2004; Grimmond et al., 2004; Offerle et al., 2006b; Goldbach and Kuttler, 2012; Kotthaus and Grimmond, 2014a; Ao et al., 2016a). At less built up suburban sites $Q_{H}$ values are, generally, negative at night as a result greater surface cooling (Grimmond and Oke, 1995; Christen and Vogt, 2004; Offerle et al., 2006a; Newton et al., 2007; Balogun et al., 2009; Goldbach and Kuttler, 2012; Ward et al., 2013, Oke et al., 2017).

At both sites negative $Q_{H}$ fluxes are observed at night but the sensible heat loss to the atmosphere, or surface cooling effects, is for longer at MY (negative flux: $11.5 \mathrm{~h}$; IAP $9.5 \mathrm{~h}$ ) and larger (nocturnal median MY: $-17.0 \mathrm{~W} \mathrm{~m}^{-2}, \mathrm{IAP}=-5.5 \mathrm{~W} \mathrm{~m}^{-2}$ ). This is related to the greater heat storage in areas with more urban area (Arnfield and Grimmond, 1998; Grimmond and Oke, 1999b).

The summer hourly median turbulent latent heat fluxes $Q_{E}$ are positive throughout the day at both sites, but with differences in diurnal pattern and amplitude (Figure 6). At IAP, $Q_{E}$ is obviously affected by human activities, with relatively higher values in the evening as at 22:00 heavy trucks are permitted entry within the $5^{\text {th }}$ Ring Road. This is independently corroborated by higher $\mathrm{CO}_{2}$ fluxes (Figure 8) at the same time (i.e. further evidence of impact of vehicle emissions).

Although daytime $Q_{E}$ maxima (IAP=122, $\mathrm{MY}=189 \mathrm{~W} \mathrm{~m}^{-2}$ ) are within the range reported previously (Grimmond et al., 2002; Goldbach and Kuttler, 2012; Miao et al., 2012), they are high compared to other sites (Figure 7b). Unusually the IAP $Q_{E}$ fluxes are similar to $Q_{H}$ throughout the day (Figure 6). Across the previous multi-month urban studies, only dense residential Tokyo observed daytime maxima and daily total $Q_{E}$ values greater than those reported at IAP (Moriwaki and Kanda, 2004). The large Tokyo $Q_{E}$ values were attributed to an "oasis effect" (Moriwaki and Kanda 2004) - the advection of hotter and/or drier air from upwind areas causing increased evaporation through leading-edge effects (Oke, 1978). The nocturnal IAP $Q_{E}$ are all $>15 \mathrm{~W}^{-2}$ (median $=20 \mathrm{~W} \mathrm{~m}^{-2}$, Figure 6) which is greater than most urban sites, even those with higher rainfall and greater vegetation cover (Balogun et al., 2009; Goldbach and Kuttler, 2012; Ward et al., 2013). In Beijing there is extra water available for evaporation from frequent road surface sprinkling at night (as part of a dust and air quality mitigation strategy), watering of greenbelts, and air conditioning usage for commercial and office buildings. 
Dou JX, CSB Grimmond, Z Cheng, S Miao, D Feng, M Liao Summertime surface energy balance fluxes at two Beijing sites, International Journal of Climatology doi:10.1002/joc.5989

At MY, $Q_{E}$ is similar to North American suburban observations (Grimmond and Oke 1995, 1999b; Balogun et al., 2009) despite $\lambda_{v}$ being samller. The combination of higher wind speeds, more easterly winds, greater vegetation density, and presence of irrigated crops all play a role.

\subsubsection{Surface energy partitioning}

To facilitate comparison of surface energy balance (SEB) partitioning between sites, the average daily, daytime $\left(K_{\downarrow}>5 \mathrm{~W} \mathrm{~m}^{-2}\right.$ or $\left.Q^{*}>0 \mathrm{~W} \mathrm{~m}^{-2}\right)$ and midday flux ratios normalized by net all-wave radiation $\left(Q^{*}\right)$ and incoming radiation $\left(Q_{\downarrow}=K_{\downarrow}+L_{\downarrow}\right)$ are summarized (Table 3). At IAP for individual 30 min periods the $Q_{H}$ was $21-25 \%$ of $Q^{*}, Q_{E} \quad 21-45 \%$ and $Q_{\text {res }} \quad 68-73 \%$; whereas at MY these proportions were between $32-34 \%, 39-66 \%$, and $16-34 \%$ of $Q^{*}$ (Table 3 ).

Unlike the absolute values (section 3.3.1), the IAP $Q_{E} / Q^{*}$ ratios are within the range of past results, whilst $Q_{H} / Q^{*}$ ratios are at the lower end (Goldbach and Kuttler, 2012; Miao et al., 2012) (Figure 9).

The calculated anthropogenic heat flux varies with air temperature and time of day. With these and when all three fluxes were measured allowed the residual term which gives some indication of storage heat flux. The higher IAP $Q_{\text {res }} / Q^{*}$ is indicative of both larger heat storage associated with the tall buildings (Miao et al., 2012) but with relatively open spacing. These values are comparable to the COSMO (Comprehensive Outdoor Scale Model experiments, Tokyo) site (Kawai and Kanda, 2010b) and Shanghai (Ao et al., 2016a), with similarly large building and impervious fractions. In such settings, there is a large area of exposed walls that can heat up (cool down) and a large canopy layer volume. Whereas the lower $Q_{H} / Q^{*}$ ratios are attributed to, among other factors, the extra water supply beyond rainfall, which also results in lower Bowen ratios (section 3.3.3).

The MY $Q_{H} / Q^{*}$ and $Q_{E} / Q^{*}$ ratios are within the ranges reported previously for suburban sites (Grimmond and Oke, 2002; Balogun et al., 2009; Goldbach and Kuttler, 2012) and very similar to fluxes observed in Chicago (Grimmond and Oke, 1995) (Figure 9), despite the Chicago observation period having frequent rain and greater vegetation cover $\left(\lambda_{v}=44.2 \%\right)$. At MY, wind came for directions with high vegetation coverage $\left(>50 \%\right.$, e.g. farmland) $30 \%$ of the time during the day $\left(30-60^{\circ}=9 \%, 90-120^{\circ}=\right.$ $15 \%$ and $120-150^{\circ}=6 \%$ ). Notably in the $90-120^{\circ}$ wind sector, farmland occupies $82 \%$ of land surface with $\lambda_{v}$ up to $88 \%$ (Figure 1e). The irrigated crops at MY enhanced the latent heat flux, leading to higher $Q_{E} / Q^{*}$ and smaller Bowen ratio values (section 3.3.3).

\subsubsection{Factors influencing the Bowen ratio $(\beta)$}

Partitioning of the available energy favours the turbulent latent heat flux at both sites. The daily mean Bowen ratios $(\beta)$ are 0.56 (IAP) and $0.49(\mathrm{MY})$, with daytime $\left(Q^{*}>0 \mathrm{~W} \mathrm{~m}^{-2}\right)$ mean values of 0.78 (Table 3). Compared to other urban flux studies, the IAP $\beta$ values are at the lower end of the range (Figure 9c). They are significantly less than high density central city sites such as Shanghai (Ao et al., 2016a) or London (Kotthaus and Grimmond, 2014a), but also lower than sites with similar or greater vegetation fraction (e.g. Tokyo, Moriwaki and Kanda, 2004; Łódź, Offerle et al., 2006a, 2006b).

Balogun et al.'s (2009) comparison of summer daytime $\beta$ values for 11 North American suburban sites reported a range of 0.472.87. Goldbach and Kuttler (2012) indicated that daytime $\beta$ values for suburban sites in European cities are between 0.28 and 2.11 during summer. Thus, MY $\beta$ are within the range reported for other suburban sites.

Generally, rainfall events control the dominance of the latent heat flux in dense urban areas for relatively short time intervals following rainfall, as surface water drains quickly from impervious surfaces. Kotthaus and Grimmond (2014a) report $\beta$ in central London suppressed for 3-6 h following rainfall. Thereafter, the ratio increases, reaching "constant" values about 12-18 h after precipitation. Similarly, Ao et al. (2016a) found $\beta$ values in a commercial and residential area of Shanghai were influenced by rainfall events for about $12 \mathrm{~h}$. However, with the frequent addition of water from other sources at IAP it is harder to separate rainfall events. As Figure 10 shows, frequently daytime $\beta<1$ occurred during 'dry' (no rainfall) spells in July and August.

Furthermore, some small $\beta$ values occurred at midday under clear skies, despite it being 10 days since the last rainfall (Figure 11).

At MY, crop irrigation plays a significant role in the energy balance and flux partitioning. During the rain free period (9-18 August), the $\beta$ values remain below 1 because of local irrigation (Figures 10,12). Whereas areas with sustained dry spells have 
Dou JX, CSB Grimmond, Z Cheng, S Miao, D Feng, M Liao Summertime surface energy balance fluxes at two Beijing sites, International Journal of Climatology doi:10.1002/joc.5989

observed an increased $\beta$ (e.g. Łódź, Offerle et al., 2006b; Swindon, Ward et al., 2013) and 50\% reduction in evaporation (e.g. Oberhausen, Goldbach and Kuttler, 2012). In Swindon, the $\beta$ increased from $<1$ following rainfall to $>4$ over 16 days without rain (Ward et al., 2013).

In July and August, the MY dry-spells flux partitioning is impacted by wind direction (Figure 13) changing the fetch (Figure 1c, e). The frequency of westerly winds is greater in the July dry spell compared to August. The enhanced proportions of impervious surfaces (smaller vegetation fractions) and reduced water content originally stored by soil and vegetation, result in lower latent heat fluxes and greater Bowen ratios.

The MY crops (wheat then maize) growth cause leaf area index (LAI) changes that influence evaporation rates (greater later in summer). This is explored using daily variations of the Priestley-Taylor aridity parameter $\left(\alpha_{P T}\right)$ (Priestley and Taylor, 1972; Eichinger, 1996) for the observation period (Figure 14).

The $\alpha_{P T}$ is the ratio of observed $Q_{E}$ to the equilibrium evaporation $\left(Q_{E q}\right.$, Slatyer and McIlroy, 1961; Eichinger, 1996; McMahon et al., 2013). In an urban area this is calculated:

$Q_{E q}=[s /(s+\gamma)]\left(Q^{*}+Q_{F}-\Delta Q_{S}\right)$

where $s$ is the slope of the saturation vapor pressure-temperature curve and $\gamma$ the psychrometric 'constant'. At MY, $\Delta Q_{S}$ is determined as a residual term of the surface energy balance; thus the right-hand term reduces to the sum of the turbulent fluxes $\left(Q_{H}+Q_{E}\right)$. Generally, cropland values of $\alpha_{P T}$ are positively related to LAI (Lei and Yang, 2010). As Figure 14 shows, with wheat harvested and maize sown but unsprouted in mid-June the crop LAI was at the observation period minima, as were the $\alpha_{P T}$ values with daily medians between 0.25 and 0.51 . After this, during crop growth, the cropland $\alpha_{P T}$ are greater than 0.5 (Figure 14).

\section{Discussion and Conclusions}

This study analyses the intra-city surface energy flux measurements in Beijing for a summer-time period (June-August 2015). Radiation and energy balance fluxes at two sites with contrasting urban land use and surface properties are compared to better understand surface-atmosphere dynamics.

The urban site (IAP) has slightly lower incoming shortwave radiation $\left(K_{\downarrow}\right)$ than the suburban site (MY), with midday mean values of $581 \mathrm{~W} \mathrm{~m}^{-2}$ and $605 \mathrm{~W} \mathrm{~m}^{-2}$, and daytime $\left(Q^{*}>0 \mathrm{~W} \mathrm{~m}^{-2}\right)$ mean values of $403 \mathrm{~W} \mathrm{~m}^{-2}$ and $417 \mathrm{~W} \mathrm{~m}^{-2}$, respectively. Transmissivity $(\tau), \quad K_{\downarrow}$ normalized by total solar radiation flux received at the top of Earth's atmosphere, mean values at midday are 0.49 and 0.51 (daytime $\tau=0.45$ and 0.46 ) at IAP and MY, respectively.

For all sky conditions, outgoing shortwave radiation $\left(K_{\uparrow}\right)$ is always lower at the urban site than suburban site, so too is the albedo. The differences in albedo between the two sites are greater during the midday period than for the daytime (0.10 and 0.11 at IAP, respectively; 0.125 and 0.129 at MY), given greater "radiation trapping" effects at IAP. The surface albedo is highest under overcast conditions at both sites. At MY, the smallest albedo values occurred under rainy conditions, as expected, attributed to wet surfaces absorbing more radiation. However, at IAP the smallest values were on clear days (with more area of shadows). At this site, building walls remained largely dry on the rainy days in this study period.

Both sites received similar incoming longwave radiation $\left(L_{\downarrow}\right)$. The suburban site has greater outgoing longwave radiation $\left(L_{\uparrow}\right)$ at midday and during the daytime than the urban site, while the difference in the daily averaged $L_{\uparrow}$ values is very small, indicating that urban site has higher $L_{\uparrow}$ at night. This is attributed to greater building density at IAP, which results in more daytime heat being absorbed and stored for release at night. The small differences of incoming and outgoing radiation between urban and suburban sites result in similar net all-wave radiation $\left(Q^{*}\right)$ values, with the midday and daily averaged values of the two sites being nearly equal.

At IAP the normalized sensible heat flux ratios $\left(Q_{H} / Q^{*}\right)$ are $21-25 \%$ for midday, daytime, and daily periods, which is low compared to other urban sites with smaller or similar vegetation fraction $\left(\lambda_{v}\right)$. The residual flux $\left(Q_{\text {res }}\right)$ (section 3.3.2) dominates the surface energy balance at IAP with the a daily ratio $68 \%$ (or $49 \%$ of $Q^{*}+Q_{F}$ ). This suggests that the large urban volume has a 
Dou JX, CSB Grimmond, Z Cheng, S Miao, D Feng, M Liao Summertime surface energy balance fluxes at two Beijing sites, International Journal of Climatology doi:10.1002/joc.5989

large net warming but the observational errors are also large (section 3.3.2). However, the values are comparable to other urban sites with tall buildings and/or large impervious fractions.

At MY, the normalised $Q_{H}, Q_{E}$ and $Q_{r e s}$ are between 32-34\%, 39-66\% and 16-34\% of $Q^{*}$ for the four time periods (Table 3). These values are consistent with many other suburban sites and very close to observed results at Chicago. The IAP and MY Bowen ratios both have greater $Q_{E}$ than $Q_{H}$. The mean daytime Bowen ratio is 0.78 for both; while the mean daily values are 0.56 and 0.49 for the urban and suburban sites, respectively. These are lower than previous urban and suburban studies with similar or larger vegetated cover fractions. The IAP values are attributed to the extra supply of water, over and above rainfall, from watering of vegetation and road surfaces, plus air conditioning. At MY, additional water is mainly from the irrigation of crops.

These surface energy balance fluxes for Beijing provide important insights into boundary layer dynamics in this city and provide much needed data for numerical model evaluations and key parameters (albedo, Bowen ratio etc) for simulations of current and future conditions. The MY site reflects a rather different suburban site (with agriculture) compared to those studied before. Further analysis of the data collected at these two sites will be undertaken to document seasonal patterns.

\section{Acknowledgments.}

This research was supported by the National Natural Science Foundation of China (Grant No. 41505102 and Grant No. 41575010) and the National Key Project of the Ministry of Science and Technology of China (Grant No. 2016YFC0203302). We give thanks to all those who supported the operations of the instrumentation in this project. We offer special thanks to Dr. Chunlei Meng, Dr. Youjun Dou, Dr. Xiya Zhang, Dr Christoph Kent, Dr Denise Hertwig and Bei Huang for assistance with the paper. SG thanks the Newton Fund/Met Office CSSP-China project and NERC AirPro (NE/N00700X/1).

\section{References}

Allen L, Lindberg F, Grimmond CSB. 2011. Global to city scale urban anthropogenic heat flux: Model and variability. International Journal of Climatology 31: 1990-2005. doi: 10.1002/joc.2210.

Al-Jiboori MH, Hu F. 2005. Surface roughness around a 325-m meteorological tower and its effect on urban turbulence. Advances in Atmospheric Sciences 22 (4): 595-605.

Ao XY, Grimmond CSB, Chang YY, Liu DW, Tang YQ, Hu P, Wang YD, Zou J, Tan JG. 2016a. Heat, water and carbon exchanges in the tall megacity of Shanghai: challenges and results. International Journal of Climatology 36:4608-4624. doi: 10.1002/joc.4657.

Ao XY, Grimmond CSB, Liu DW, Han ZH, Hu P, Wang YD, Zhen XR, Tan J G. 2016b. Radiation fluxes in a business district of Shanghai, China. Journal of Applied Meteorology and Climatology 55: 2451-2468. doi: 10.1175/JAMC-D-16-0082.1.

Arnfield AJ, Grimmond CSB. 1998. An urban canyon energy budget model \& its application to urban storage heat flux modelling. Energy \& Buildings 27: 61-68.

Aubinet M, Grelle A, Ibrom A, Rannik Ü, Moncrieff J, Foken T, Kowalski AS, Martin PH, Berbigier P, Bernhofer CH, Clement R, Elbers J, Granier A, GrÜnwald T, Morgenstern K, Pilegaard K, Rebmann C, Snijders W, Valentini R, Vesala T. 2000. Estimates of the annual net carbon and water exchange of European forests: The EUROFLUX methodology. Advances in Ecological Research 30: 113-175. doi: 10.1016/S0065-2504(08)60018-5.

Balogun AA, Adegoke JO, Vezhapparambu S, Mauder M, McFadden JP, Gallo K. 2009. Surface energy balance measurements above an exurban residential neighbourhood of Kansas City, Missouri. Boundary-Layer Meteorology 133: 299-321. doi: 10.1007/s10546-009-9421-3.

Beijing Municipal Bureau of Statistics. 2016. Beijing Statistical Yearbook, 2016.

Beijing statistical information net. http://www.bjstats.gov.cn/tjsj/

Beijing Municipal Bureau of Statistics, Permanent population (1978-2016), 2017. Beijing: Beijing statistical information net. (Published in July 26, 2017). http://www.bjstats.gov.cn/tjsj/cysj/201511/t20151109_311727.html

Best MJ, Grimmond CSB. 2015. Key conclusions of the first international urban land surface model comparison project. Bulletin of the American Meteorological Society 96 (5): 805-819. doi: https://doi.org/10.1175/BAMS-D-14-00122.1

Bergeron O, Strachan IB. 2012. Wintertime radiation and energy budget along an urbanization gradient in Montreal, Canada. International Journal of Climatology 32: 137-152. doi: 10.1002/joc.2246.

Center for International Earth Science Information Network, Columbia University, 2016. Gridded Population of the World, Version 4 (GPWv4): Population Count Grid. Palisades, NY: NASA Socioeconomic Data and Applications Center (SEDAC).

http://sedac.ciesin.columbia.edu/data/set/gpw-v4-population-density/metadata 
Dou JX, CSB Grimmond, Z Cheng, S Miao, D Feng, M Liao Summertime surface energy balance fluxes at two Beijing sites, International Journal of Climatology doi:10.1002/joc.5989

Chan CK, Yao XH. 2008. Air pollution in mega cities in China. Atmospheric Environment 42:1-42. doi:10.1016/j.atmosenv.2007.09.003

China Centre for Resources Satellite Data and Application, China Aerospace Science and Technology Corporation, 2016. GF-2 (Gaofen-2) Highresolution Image.

http://218.247.138.119:7777/DSSPlatform/productSearch.html

Christen A, Vogt R. 2004. Energy and radiation balance of a central European city. International Journal of Climatology 24: 1395-1421. doi: 10.1002/joc.1074.

Coutts AM, Beringer J, Tapper NJ. 2007. Impact of increasing urban density on local climate: spatial and temporal variations in the surface energy balance in Melbourne, Australia. Journal of Applied Meteorology and Climatology 46: 477-493. doi: 10.1175/JAM2462.1.

Duffie JA, Beckman WA. 2013. Solar Engineering of Thermal Processes, John Wiley and Sons Inc.: Hoboken, New Jersey. pp 75-77.

Eichinger WE. 1996. On the concept of equilibrium evaporation and the value of the Priestley-Taylor coefficient. Water Resources Research 32: 161-164. doi: 10.1029/95WR02920.

Flerchinger GN, Xaio W, Marks D, Sauer TJ, Yu Q. 2009. Comparison of algorithms for incoming atmospheric longwave radiation. Water Resources Research 45: W03423. doi: 10.1029/2008WR007394.

Frey CM, Parlow E, Vogt R, Harhash M, Wahab MMA. 2011. Flux measurements in Cairo. Part 1: in situ measurements and their applicability for comparison with satellite data. International Journal of Climatology 31: 218-231. doi: 10.1002/joc.2140.

Gabey A, Grimmond S, Capel-Timms I. 2018. Anthropogenic Heat Flux: advisable spatial resolutions when input data are scarce. Theoretical and Applied Climatology https://doi.org/10.1007/s00704-018-2367-y

Goldbach A, Kuttler W. 2012. Quantification of turbulent heat fluxes for adaptation strategies within urban planning. International Journal of Climatology 33(1):143-159. doi: 10.1002/joc.3437.

Grimmond CSB, Oke TR. 1995. Comparison of heat fluxes from summertime observations in the suburbs of four North American cities. Journal of Applied Meteorology 34: 873-889.

Grimmond CSB, Oke TR. 1999a. Aerodynamic properties of urban areas derived, from analysis of surface form. Journal of Applied Meteorology 34:873-889.

Grimmond CSB, Oke TR. 1999b. Heat storage in urban areas: local-scale observations and evaluation of a simple model. Journal of Applied Meteorology 38:922-940.

Grimmond CSB, Oke TR. 2002. Turbulent heat fluxes in urban areas: Observations and a local-scale urban meteorological parameterization scheme (LUMPS). Journal of Applied Meteorology 41(7): 792- 810.

Grimmond CSB, Salmond JA, Oke TR, Offerle B, Lemonsu A. 2004. Flux and turbulence measurements at a densely built-up site in Marseille: heat, mass (water and carbon dioxide), and momentum. Journal of Geophysical Research 109 (D24): 241011-24120. doi: 10.1029/2004JD004936.

Guo WD, Wang XQ, Sun JN, Ding AJ, Zou J. 2016. Comparison of land-atmosphere interaction at different surface types in the mid- to lower reaches of the Yangtze River valley. Atmospheric Chemistry and Physics 16: 9875-9890. doi:10.5194/acp-16-9875-2016.

Hertwig D, Gough H, Grimmond CSB, Barlow J, Kent C, Lin W, A Robins. Wake characteristics of tall buildings in a complex urban canopy. Boundary-Layer Meteorology (in review).

Huang H, Li YH, Han SQ, Wu BG, Zhang YX, Li C. 2011. Turbulent statistic characteristic of the urban boundary layer in Tianjin. Plateau Meteorology 30: 1481-1487 (in Chinese).

Kanda M, Inagaki A, Miyamoto T, Gryschka M, Raasch S. 2013. A new aerodynamic parametrization for real urban surfaces. Boundary-Layer Meteorology 148: 357-377. doi: 10.1007/s10546-013-9818-x.

Kawai T, Kanda M. 2010a. Urban energy balance obtained from the comprehensive outdoor scale model experiment. Part I: Basic features of the surface energy balance. Journal of Applied and Climatology 49: 1341-1359. doi: 10.1175/2010JAMC1992.1

Kawai T, Kanda M. 2010b. Urban energy balance obtained from the comprehensive outdoor scale model experiment. Part II: comparisons with field data using an improved energy partition. Journal of Applied Meteorology and Climatology 49: 1360-1376. doi: 10.1175/2010JAMC1993.1.

Kent CW, Grimmond CSB, Barlow J, Gatey D, Kotthaus S, Lindberg F, Halios CH. 2017. Evaluation of urban local-scale aerodynamic parameters: implications for the vertical profile of wind and source areas. Boundary Layer Meteorology 164: 183-213. doi: 10.1007/s10546-017-0248-z.

Kljun N, Calanca P, Rotach MW, Schmid HP. 2004. A simple parameterization for flux footprint predictions. Boundary-Layer Meteorology 112: 503-523. doi: 10.1023/B:BOUN.0000030653.71031.96.

Kotthaus S, Grimmond CSB. 2014a. Energy exchange in a dense urban environment- Part I: temporal variability of long-term observations in 
Dou JX, CSB Grimmond, Z Cheng, S Miao, D Feng, M Liao Summertime surface energy balance fluxes at two Beijing sites, International Journal of Climatology doi:10.1002/joc.5989

central London. Urban Climate 10: 261-280. doi: 10.1016/j.uclim.2013.10.002.

Kotthaus S, Grimmond CSB. 2014b. Energy exchange in a dense urban environment- Part II: impact of spatial heterogeneity of the surface. Urban Climate 10: 281-307. doi: 10.1016/j.uclim.2013.10.001.

Lei HM, Yang DW. 2010. Interannual and seasonal variability in evapotranspiration and energy partitioning over an irrigated cropland in the North China Plain. Agricultural and Forest Meteorology 150: 581-589. doi:10.1016/j.agrformet.2010.01.022.

Li Q, Liu HZ, Hu F, Hong ZX, Li AG. 2003. The determination of the aerodynamical parameters over urban land surface. Climatic and Environment Research 8 (4): 443-450. (in Chinese)

LI-COR, Inc. 2017. EddyPro software instruction manual. 7-75pp. https://www.licor.com/env/help/eddypro/topics_eddypro/EddyPro_Home.html

Lindberg F, Grimmond CSB, Gabey A, Huang B, Kent CW, Sun T, Theeuwes NE, Järvi L, Ward H, Capel-Timms I, Chang YY, Jonsson P, Krave N, Liu DW, Meyer D, Olofson KFG, Tan JG, Wästberg D, Xue L, Zhang Z. 2018. Urban multiscale environmental predictor (UMEP) An integrated tool for city-based climate services. Environmental Modelling and Software 99: 70-87. doi: 10.1016/j.envsoft.2017.09.020.

Lindberg F, Grimmond CSB, Yogeswaran N, Kotthaus S, Allen L. 2013. Impact of city changes and weather on anthropogenic heat flux in Europe 1995-2015. Urban Climate 4: 1-15.

Liu HZ, Feng JW, Järvi L, Vesala T. 2012. Four-year (2006-2009) eddy covariance measurements of $\mathrm{CO}_{2}$ flux over an urban area in Beijing. Atmospheric Chemistry and Physics 12: 7881-7892. doi:10.5194/acp-12-7881-2012.

McMahon TA, Peel MC, Lowe L, Srikanthan R, McVicar TR. 2013. Estimating actual, potential, reference crop and pan evaporation using standard meteorological data: a pragmatic synthesis. Hydrology and Earth System Sciences 17: 1331-1363. doi: 10.5194/hess-17-13312013.

Miao SG, Dou JX, Chen F, Li J, Li AG. 2012. Analysis of observations on the urban surface energy balance in Beijing. Science China Earth Science 55(11): 1881-1890. doi: 10.1007/s11430-012-4411-6.

Millward-Hopkins JT, Tomlin AS, Ma L, Ingham D, Pourkashanian M. 2011. Estimating aerodynamic parameters of urban-like surfaces with heterogeneous building heights. Boundary-Layer Meteorology 141: 443-465. doi: https://doi.org/10.1007/s10546-011-9640-2.

Moncrieff JB, Massheder JM, de Bruin H, Elbers J, Friborg T, Heusinkveld B, Kabat P, Scott S, Soegaard H, Verhoef A. 1997. A system to measure surface fluxes of momentum, sensible heat, water vapour and carbon dioxide. Journal of Hydrology 188-199: 589-611. doi: 10.1016/S0022-1694(96)03194-0.

Moriwaki R, Kanda M. 2004. Seasonal and diurnal fluxes of radiation, heat, water vapor, and carbon dioxide over a suburban area. Journal of Applied Meteorology and Climatology 43(11): 1700-1710.

Newton T, Oke TR, Grimmond CSB, Roth M. 2007. The suburban energy balance in Miami, Florida. Geografiska Annaler Series A-Physical Geography 89(4): 331-347.

Offerle B, Grimmond CSB, Fortuniak K, Kłysik K, Oke TR. 2006a. Temporal variations in heat fluxes over a central European city centre. Theoretical and Applied Climatology 84(1-3): 103-115. doi: 10.1007/s00704-005-0148-x.

Offerle B, Grimmond CSB, Fortuniak K, Pawlak W. 2006b. Intraurban differences of surface energy fluxes in a central European city. Journal of Applied Meteorology and Climatology 45: 125-136.

Oke, T. R. (1978) Boundary Layer Climates. Methuen \& Co Ltd, London.

Oke, T. R., 1988: The urban energy balance. Progress in Physical Geography 12: 471-508.

Oke, T. R., Mills, G., Christen, A., Voogt, J. A. (2017) Urban Climates. Cambridge: Cambridge University Press. 525pp. DOI: $10.1017 / 9781139016476$.

Peng J, Grimmond CSB, Fu XS, Chang YY, Zhang G, Guo Jibing, Tang CY, Gao J, Xu XD, Tan JG. 2017. Ceilometer based analysis of Shanghai's boundary layer height (under rain and fog free conditions). Journal Atmospheric and Oceanic Technology 34: 749-764. doi: 10.1175/JTECH-D-16-0132.1.

Peng JL, Wu X, Jiang ZH, Liu HN. 2008. Characteristics analysis of energy budget over urban and suburban underlying surfaces in Nanjing. Scientia Meteorologia Sinica 28: 21-29 (in Chinese).

Peng Z, Hu F. 2006. A study of the influence of urbanization of Beijing on the boundary wind structure. Chinese Journal of Geophysics 49(6): 1608-1615. (in Chinese)

Priestley CHB, Taylor RJ. 1972. On the assessment of surface heat flux and evaporation. Monthly Weather Review 106: 81-92.

Raupach MR. 2001. Combination theory and equilibrium evaporation. Quarterly Journal of the Royal Meteorological Society 127: 1149-1181. doi: $10.1002 /$ qj.49712757402.

Rotach MW, Vogt R, Bernhofer C, Batchvarova E, Christen A, Clappier A, Feddersen B, Gryning SE, Martucci G, Mayer H, Mitev V, Oke TR, 
Dou JX, CSB Grimmond, Z Cheng, S Miao, D Feng, M Liao Summertime surface energy balance fluxes at two Beijing sites, International Journal of Climatology doi:10.1002/joc.5989

Parlow E, Richner H, Roth M, Roulet Y A, Ruffieux D, Salmond JA, Schatzmann M, Voogt JA. 2005. BUBBLE- an urban boundary layer meteorology project. Theoretical and Applied Climatology 81: 231-261. doi: 10.1007/s00704-004-0117-9.

Roth M. 2000. Review of atmospheric turbulence over cities. Quarterly Journal of the Royal Meteorological Society 126: 941-990. doi: 10.1002/qj.49712656409.

Roth M, Jansson C, Velasco E. 2017. Multi-year energy balance and carbon dioxide fluxes over a residential neighbourhood in a tropical city. International Journal of Climatology 37: 2679-2698. doi:10.1002/joc.4873.

Schmid HP, Cleugh HA, Grimmond CSB, Oke TR. 1991. Spatial variability of energy fluxes in suburban terrain. Boundary-Layer Meteorology 54: 249-276. doi: 10.1007/bf00183956.

Slatyer RO, McIlroy IC. 1961. Practical microclimatology, CSIRO, Melbourne, Australia, 310pp.

Spronken-Smith RA. 2002. Comparison of summer- and winter-time suburban energy fluxes in Christchurch, New Zealand. International Journal of Climatology 22: 979-992. doi:10.1002/joc.767.

Statistics Bureau of Miyun District, Beijing. 2016. Beijing Miyun Statistical Yearbook 2016. http://tjj.bjmy.gov.cn/Page-483

Stewart ID, Oke TR. 2012. Local climate zones for urban temperature studies. Bulletin of the American Meteorological Society 93(12): 18791900. doi: 10.1175/BAMS-D-11-00019.1.

UN-Habitat. 2016. United Nations Human Settlements Programme: Urbanization and development: emerging futures, World Cities Report 2016, UN-Habitat. http://wcr.unhabitat.org/main-report.

Vesala T, Ja“rvi L, Launiainen S, Sogachev A, Rannik U“, Mammarella I, Siivola E, Keronen P, Rinne J, Riikonen A, Nikinmaa E. 2008. Surface-atmosphere interactions over complex urban terrain in Helsinki, Finland. Tellus, Series B: Chemical and Physical Meteorology 60(2): 188-199. doi: 10.1111/j.1600-0889.2007.00312.x.

Wang K, Dickinson RE. 2013. Global atmospheric downward longwave radiation at the surface from ground-based observations, satellite retrievals, and reanalyses. Reviews of Geophysics 51: 150-185. doi: 10.1002/rog.20009.

Wang LL, Gao ZQ, Miao SG, Guo XF, Sun T, Liu MF, Li D. 2015. Contrasting characteristics of the surface energy balance between the urban and rural areas of Beijing. Advances in Atmospheric Sciences 32 (4): 505-514. doi: 10.1007/s00376-014-3222-4.

Ward HC, Evans JG, Grimmond CSB. 2013. Multi-season eddy covariance observations of energy, water and carbon fluxes over a suburban area in Swindon, UK. Atmospheric Chemistry and Physics 13: 4645-4666. doi: 10.5194/acp-13-4645-2013.

Webb E, Pearman G, Leuning R. 1980. Correction of the flux measurements for density effects due to heat and water vapour transfer. Quarterly Journal of the Royal Meteorological Society 106: 85-100.

Weber S, Kordowski K. 2010. Comparison of atmospheric turbulence characteristics and turbulent fluxes from two urban sites in Essen, Germany. Theoretical and Applied Climatology 102: 61-74. doi: 10.1007/s00704-009-0240-8.

Yao XH, Chan CK, Fang M, Cadle S, Chan T, Mulawa P, He KB, Ye BM. 2002. The water-soluble ionic composition of PM2.5 in Shanghai and Beijing, China. Atmospheric Environment 36: 4223-4234. doi: 10.1016/S1352-2310(02)00342-4.

Yin DZ, Hong ZX. 1999. Study on the boundary layer structure and parameters under heavy pollution conditions in Beijing. Climatic and Environment Research 4 (3): 303-307. (in Chinese)

Zhang JY, Wu LY, Yuan F, Dou JJ, Miao SG. 2015. Mass human migration and Beijing's urban heat island during the Chinese New Year holiday. Science Bulletin 60: 1038-1041. doi: 10.1007/s11434-015-0809-9.

Zhang YL, Cao F. 2015. Fine particulate matter $\left(\mathrm{PM}_{2.5}\right)$ in China at a city level. Scientific Reports 5: 14884. doi: 10.1038/srep14884.

Zhang YZ, Miao SG, Dai YJ, Liu YH. 2013. Numerical simulation of characteristics of summer clear day boundary layer in Beijing and the impact of urban underlying surface on sea breeze. Chinese Journal of Geophysics 56: 2558-2573. doi: 10.6038/cjg20130806 (in Chinese).

Zhao XJ, Zhang XL, Xu XF, Xu J, Meng W, Pu WW. 2009. Seasonal and diurnal variations of ambient PM2.5 concentration in urban and rural environments in Beijing. Atmospheric Environment 43: 2893-2900. doi: 10.1016/j.atmosenv.2009.03.009.

Zhao XJ, Zhao PS, Xu J, Meng W, Pu WW, Dong F, He D, Shi QF. 2013. Analysis of a winter regional haze event and its formation mechanism in the North China Plain. Atmospheric Chemistry and Physics 13: 5685-5696. doi: 10.5194/acp-13-5685-2013.

Zhao XS, Guan DX, Wu JB, Jin CJ, 2004. Zero-plane displacement and roughness length of the mixed forest of broad-leaved and Korean-pine in Changbai Mountain. Chinese Journal of Ecology 23: 84-88. (in Chinese)

Zou J, Sun JN, Liu G. 2011. Turbulence characteristics in the urban surface layer. Journal of the Meteorological Sciences 31(4): 525-533. (in Chinese) 
Dou JX, CSB Grimmond, Z Cheng, S Miao, D Feng, M Liao Summertime surface energy balance fluxes at two Beijing sites, International Journal of Climatology doi:10.1002/joc.5989

Figure 1. Location and characteristics of the urban (IAP) and suburban (MY) flux sites within Beijing: (a) topography around Beijing (inset red dot location within China); (b) IAP (Yuan Dynasty Capital City Park is indicated by yellow rectangles) and (c) MY; (d) building heights around IAP tower (white dot) (2012 dataset from China Academy of Building Research); (e) land cover ( $30^{\circ}$ wind sectors) within $500 \mathrm{~m}$ radius of the MY flux tower (based on satellite imagery: Google Earth 2017).
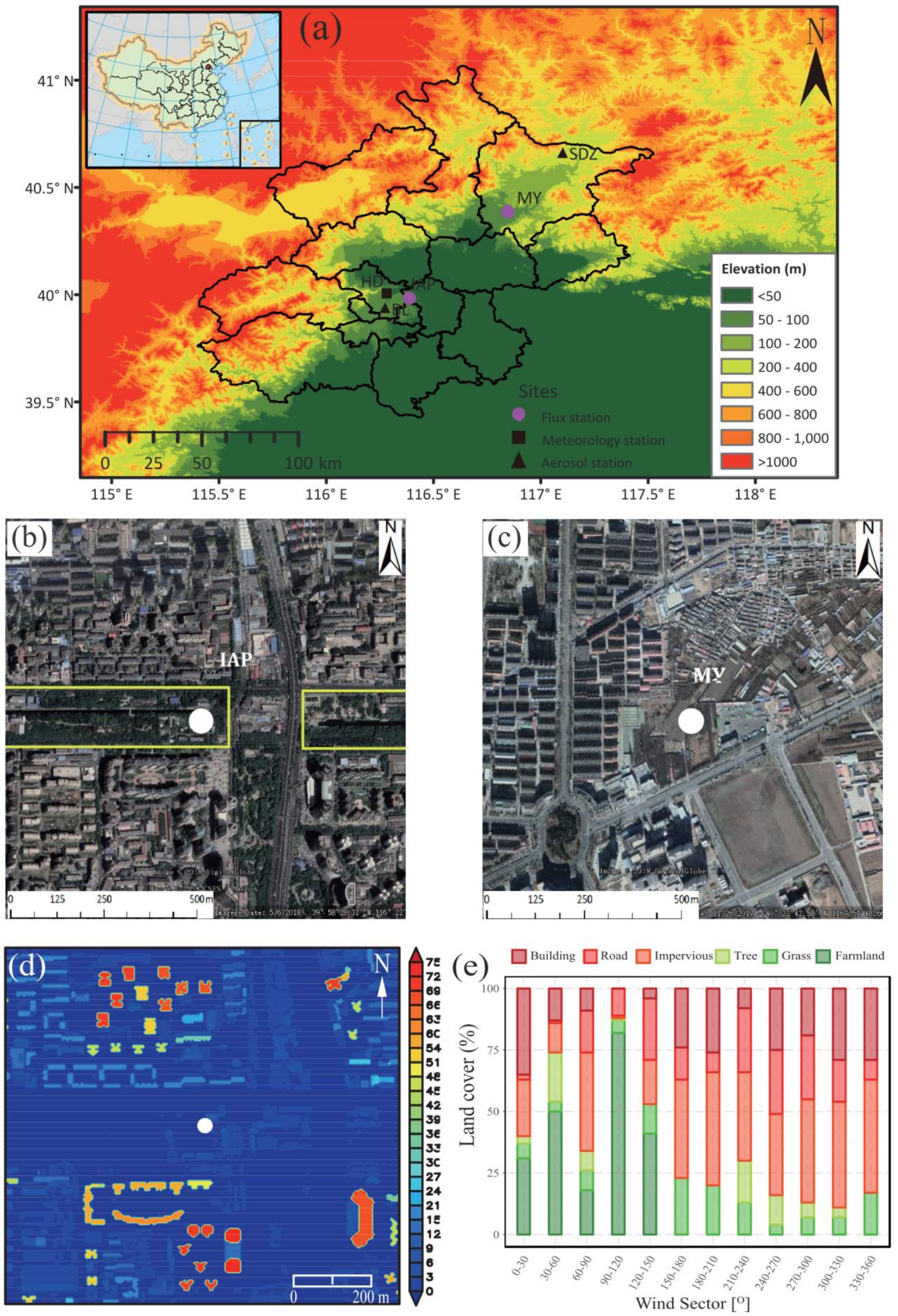
Dou JX, CSB Grimmond, Z Cheng, S Miao, D Feng, M Liao Summertime surface energy balance fluxes at two Beijing sites, International Journal of Climatology doi:10.1002/joc.5989

Figure 2. Probable eddy covariance flux source areas (50\%, 70\% and 90\%, yellow lines inside to outside) weighted by the atmospheric stability conditions during the period of 1 June to 31 August 2015 calculated using the Kljun et al. (2004) footprint model for (a) IAP and (b) MY. See text for other assumptions.
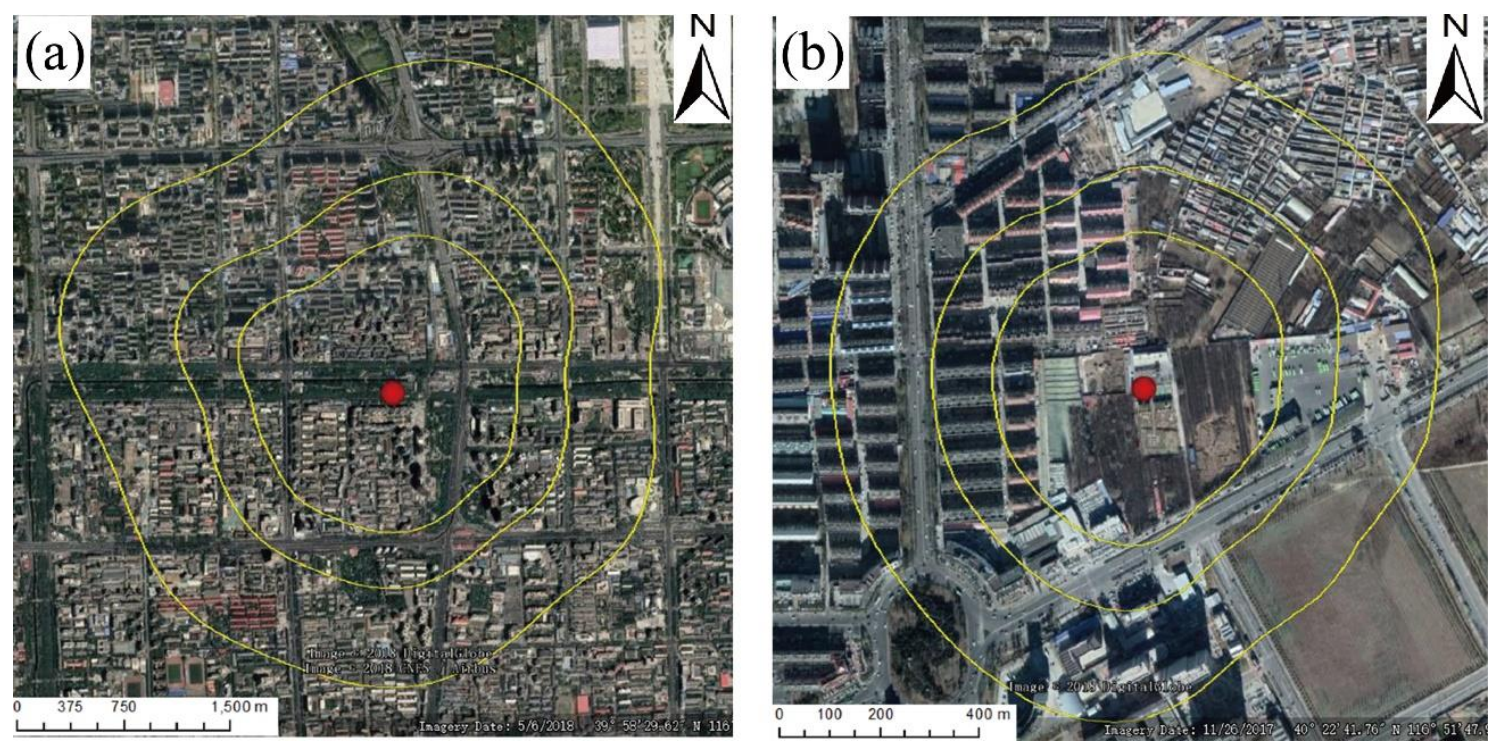
Dou JX, CSB Grimmond, Z Cheng, S Miao, D Feng, M Liao Summertime surface energy balance fluxes at two Beijing sites, International Journal of Climatology doi:10.1002/joc.5989

Figure 3. Comparison of atmospheric conditions at IAP and MY for the observation period (a) daily mean air temperatures ( $\mathrm{T}_{\mathrm{a}}$ ), daily rainfall and sky conditions (clear, overcast, rainy, see text for definitions); (b-g) wind roses ( $30^{\circ}$ bins, 30 min data) stratified by wind speed frequency for (b, c, d) IAP (height: $140 \mathrm{~m}$ ) and (e, f, g) MY (height: $36 \mathrm{~m}$ ) for (b, e) daytime, (c, f) nighttime and (d, g) all days.
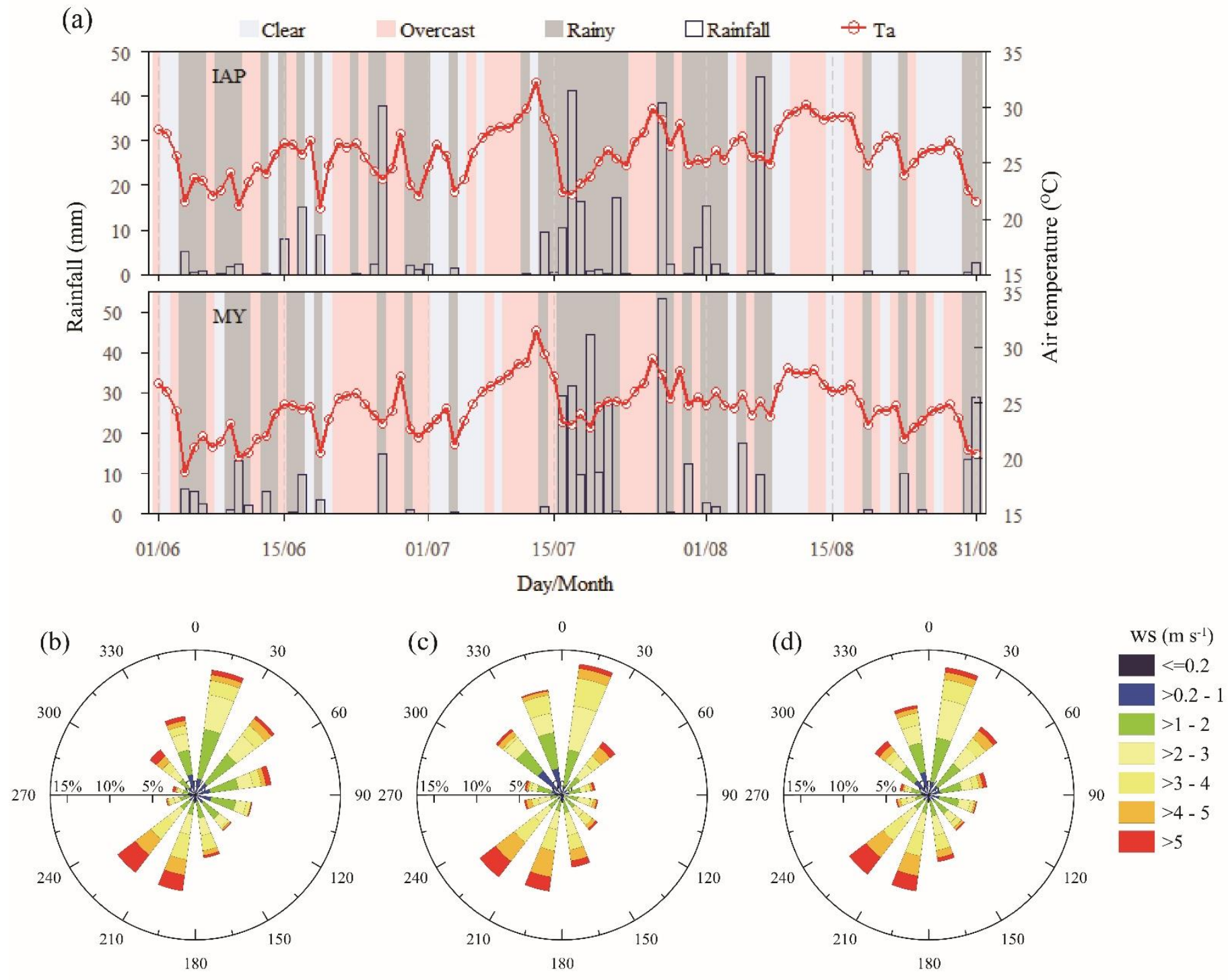

WS $\left(\mathrm{m} \mathrm{s}^{-1}\right)$
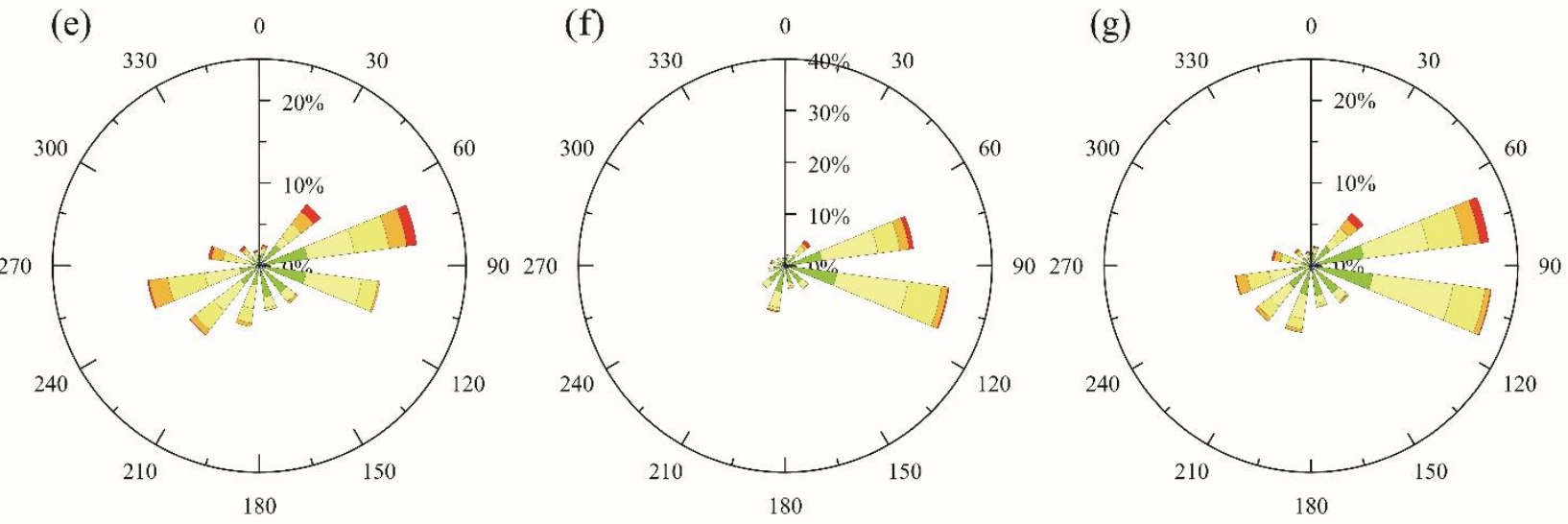
Dou JX, CSB Grimmond, Z Cheng, S Miao, D Feng, M Liao Summertime surface energy balance fluxes at two Beijing sites, International Journal of Climatology doi:10.1002/joc.5989

Figure 4. Median diurnal variations (lines) and interquartile ranges (shading) of radiation balance fluxes $\left(K_{\downarrow}, K_{\uparrow}, L_{\downarrow}, L_{\uparrow}, Q^{*}\right)$ under clear (blue), overcast (pink), and rainy (grey) conditions in the measurement period at (a, c, e, g) IAP and (b, d, f, h) MY.

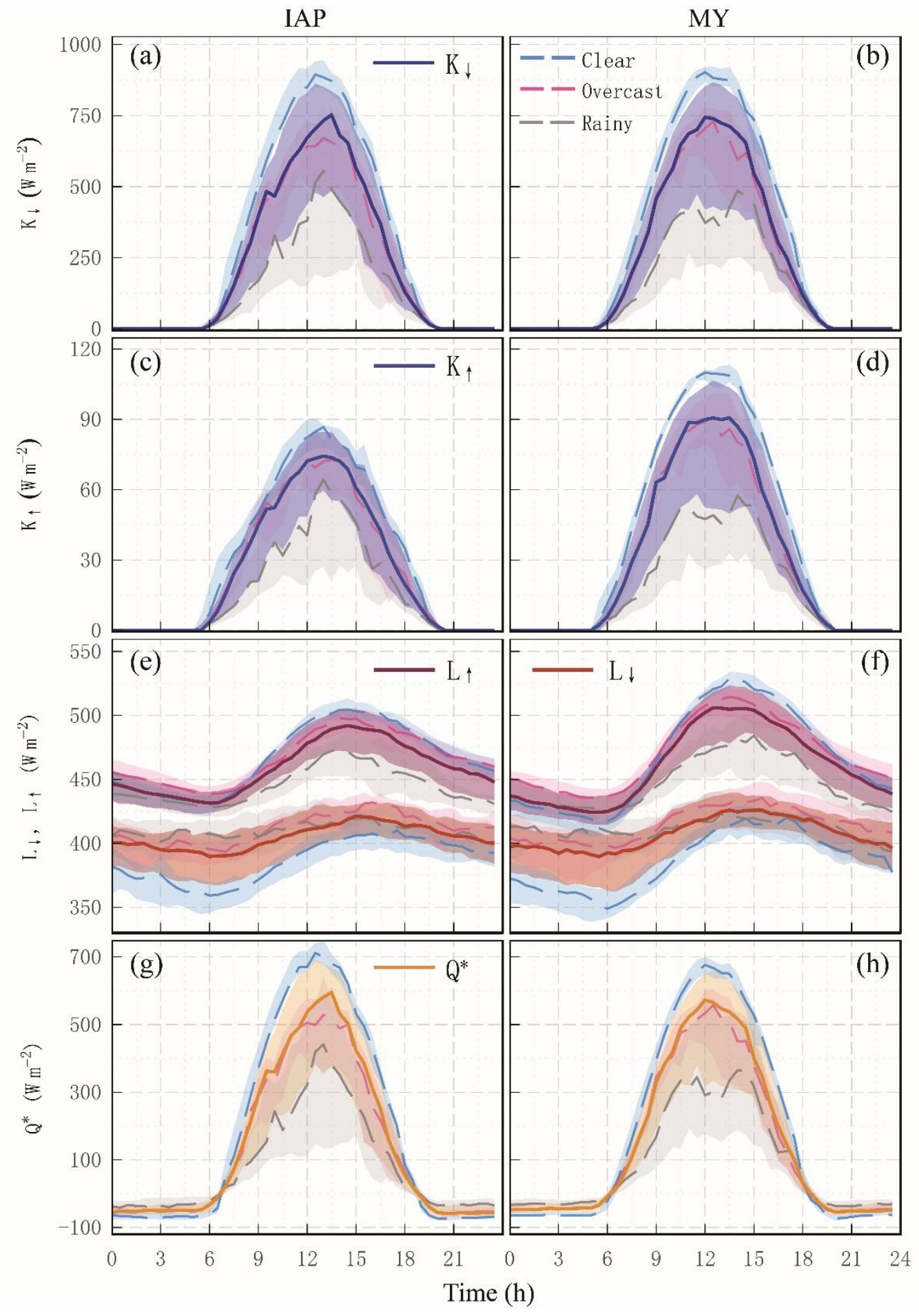


Dou JX, CSB Grimmond, Z Cheng, S Miao, D Feng, M Liao Summertime surface energy balance fluxes at two Beijing sites, International Journal of Climatology doi:10.1002/joc.5989

Figure 5. Median diurnal variations of (a-d) transmissivity and (e-f) surface albedo for (a, e) clear, (b, f) overcast, (c, g) rainy and (d, h) all sky conditions for the measurement period at IAP and MY.

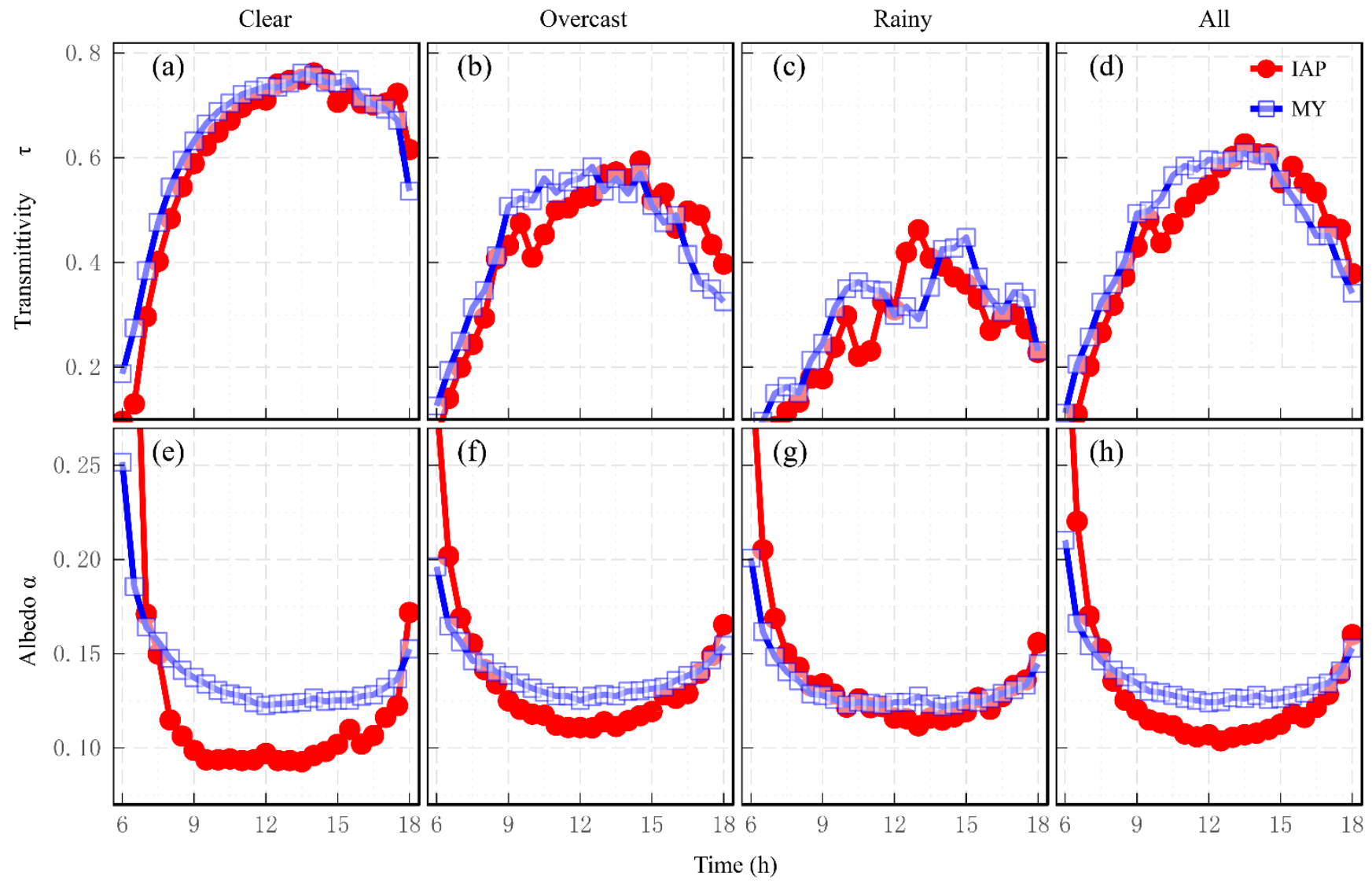

Figure 6. Median diurnal variations (points) and interquartile ranges (shading) of turbulent sensible heat flux density $\left(Q_{H}\right)$ and turbulent latent heat flux density $\left(Q_{E}\right)$ at (a) IAP and (b) MY for the measurement period (June - August 2015).
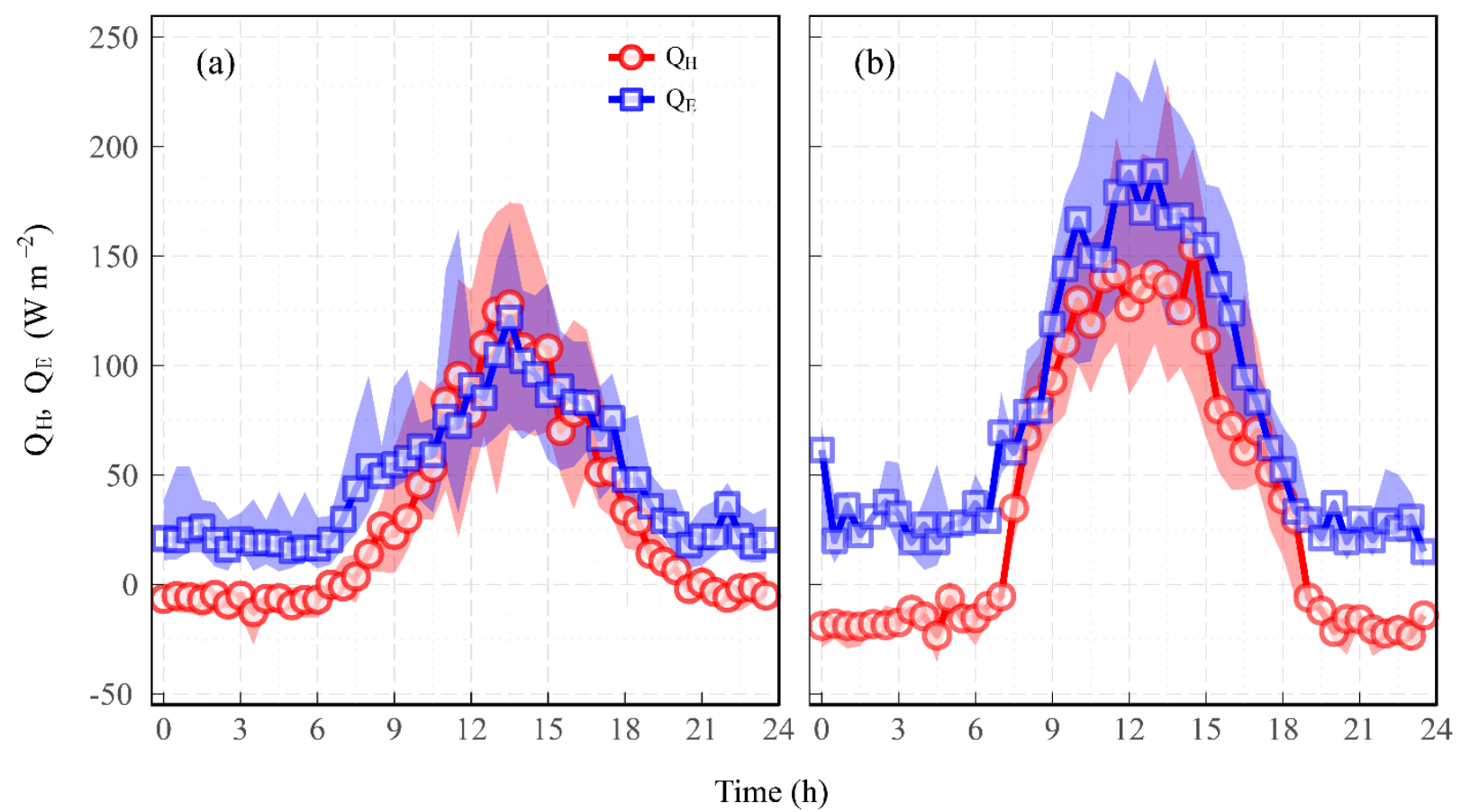
Dou JX, CSB Grimmond, Z Cheng, S Miao, D Feng, M Liao Summertime surface energy balance fluxes at two Beijing sites, International Journal of Climatology doi:10.1002/joc.5989

Figure 7. Summer maxima of (a) $Q_{H}$ and (b) $Q_{E}$ at urban (red) and suburban (blue) EC measurement sites with different vegetation cover $\left(\lambda_{\mathrm{v}}\right)$. Data sources:

(i) both $Q_{H}$ and $Q_{E}$ extracted from plots: Basel/BUBBLE (Ba02s1, Ba02u1, Ba02u2) (Christen and Vogt 2004); Christchurch (Chr96)

(Spronken-Smith 2002); Łódz (Lo02c, Lo02i, Lo02re, Lo02ru) (Offerle et al. 2006b); KSS/London (Lon11) (Kotthaus and Grimmond 2014a); Marseille (Ma01) (Grimmond et al. 2004); Fair site/Miami (Mi95) (Newton at al. 2007) and Tokyo (Tk01) (Moriwaki and Kanda 2004);

(ii) $Q_{H}$ extracted from plots and $Q_{E}$ accurately provided in paper: Vegetation sector/Helsinki (He06v) (Vesala et al. 2008); Oberhausen (Ob10s, Ob10u) (Goldbach and Kuttler 2012);

(iii) $Q_{H}$ accurately provided in paper and $Q_{E}$ extracted from plots: Arcadia (Ar93), Chicago (Ch92), Sacramento (Sc91u) and Tucson (Tu90u) (Grimmond and Oke 1995); Urban site/Helsinki (He06u) (Vesala et al. 2008) and Kansas City (Kc04) (Balogun et al. 2009);

(iv) both $Q_{H}$ and $Q_{E}$ accurately provided in paper: Beijing: Miyun, suburb (MY) (this study); IAP/Beijing (IAP) (this study); Shanghai (Sh16u) (Ao et al. 2016a) and Swindon (Sw11) (Ward et al. 2013)].

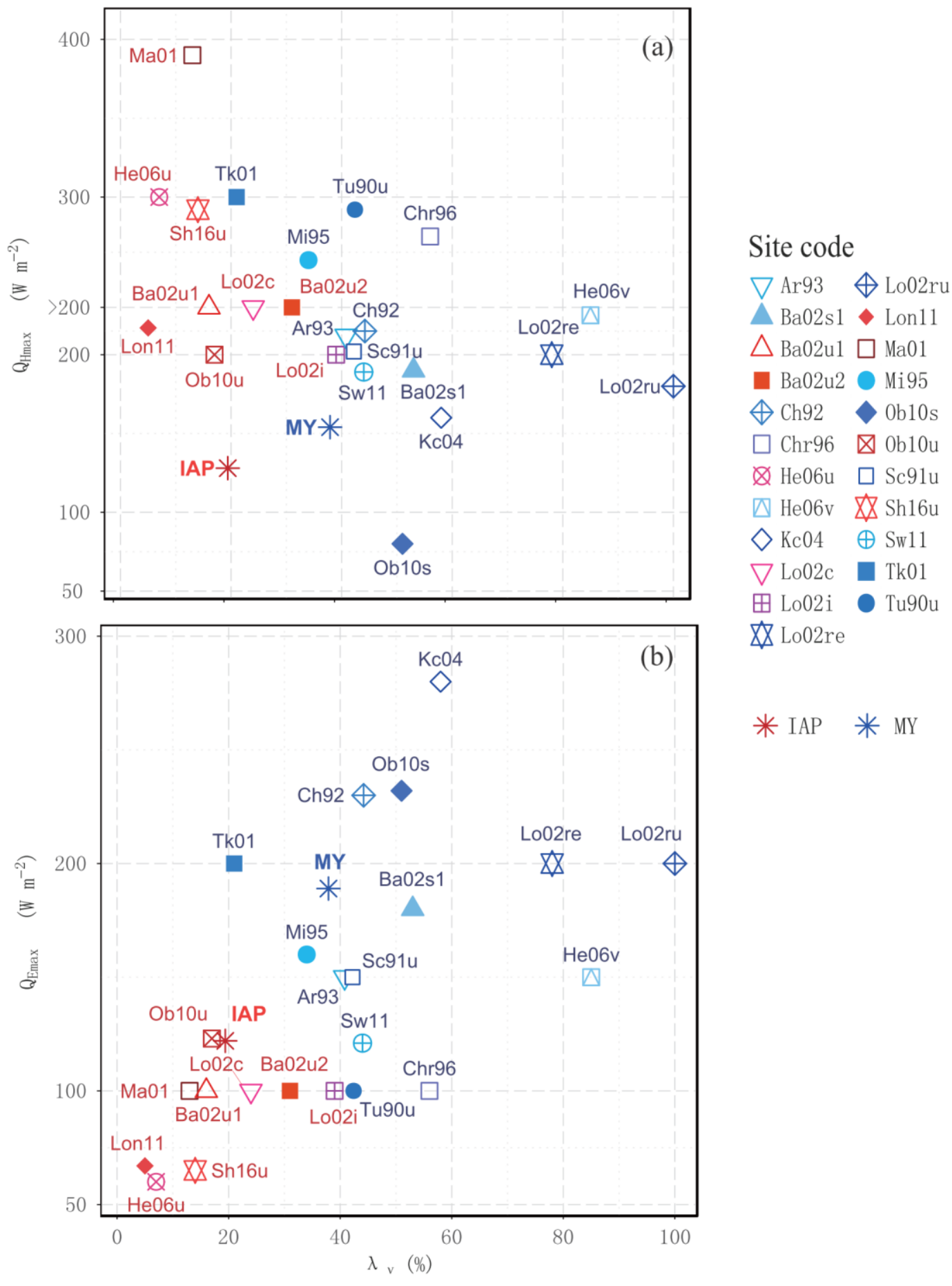


Dou JX, CSB Grimmond, Z Cheng, S Miao, D Feng, M Liao Summertime surface energy balance fluxes at two Beijing sites, International Journal of Climatology doi:10.1002/joc.5989

Figure 8. Median diurnal variations (points) and interquartile ranges (shading) for different types of day for: (a) $Q_{E}$ and (b) $\mathrm{CO}_{2}$ flux at IAP for the measurement period.
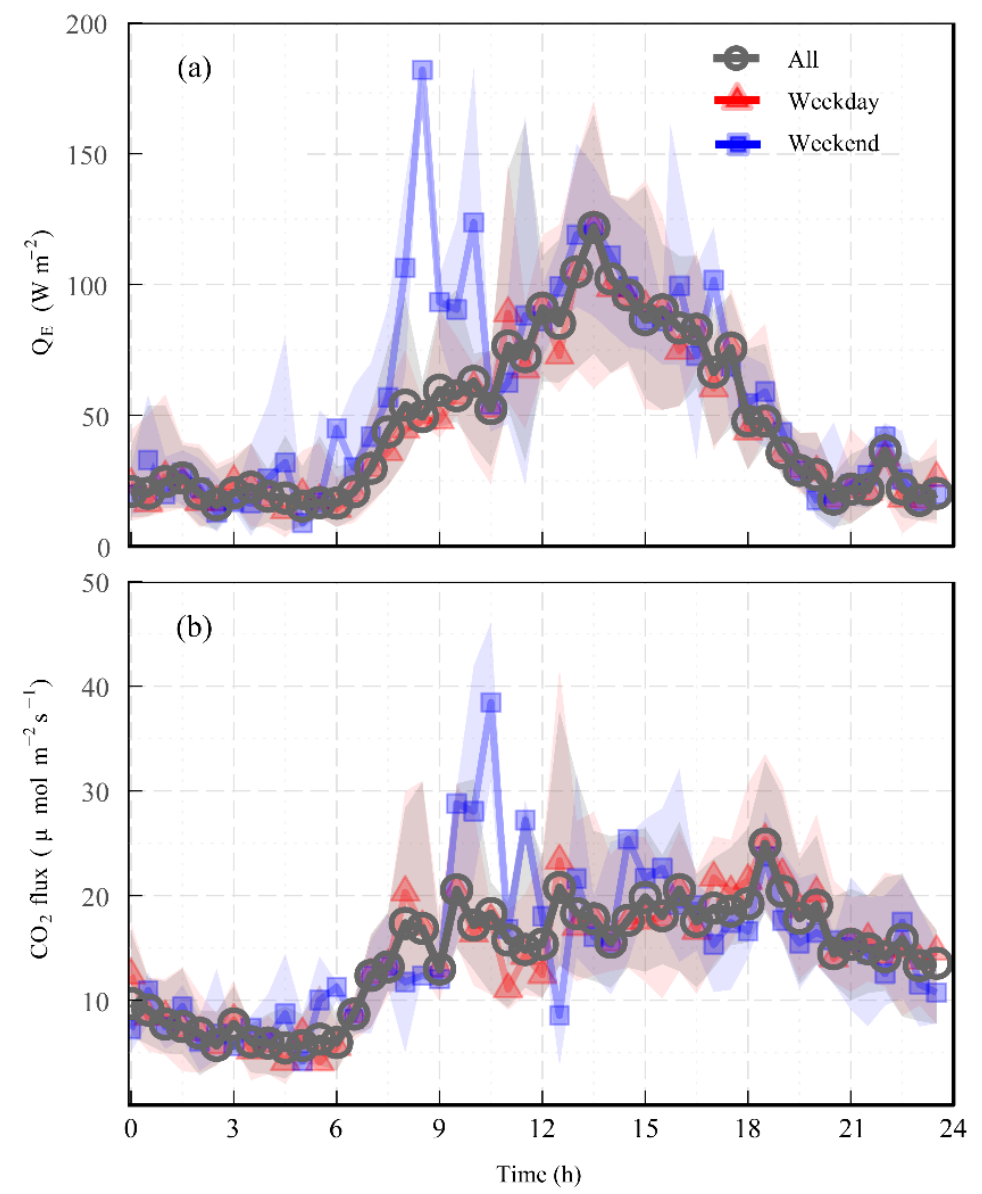
Dou JX, CSB Grimmond, Z Cheng, S Miao, D Feng, M Liao Summertime surface energy balance fluxes at two Beijing sites, International Journal of Climatology doi:10.1002/joc.5989

Figure 9. Variation with vegetation cover $\left(\lambda_{v}\right)$ of mean daytime $\left(Q^{*}>0 \mathrm{~W} \mathrm{~m}{ }^{-2}\right)$ turbulent energy partitioning (a) $Q_{H} / Q^{*}$, (b) $Q_{E} / Q^{*}$ and (c) Bowen ratio for various sites [see Figure 7 for sources and sites, except for rural sites of Basel/BUBBLE (Ba02r1, Ba02r2) (Christen and Vogt 2004), urban site of Beijing (Bj09) (Miao et al. 2012) and Vancouver light industrial site (V192) (Grimmond and Oke 1999)]. Negative linear regression, exponential regression and logarithmic regression equations describe (a) $Q_{H} / Q^{*}$, (b) $Q_{E} / Q^{*}$ and (c) Bowen ratio as a function of $\lambda_{v}$ separately.

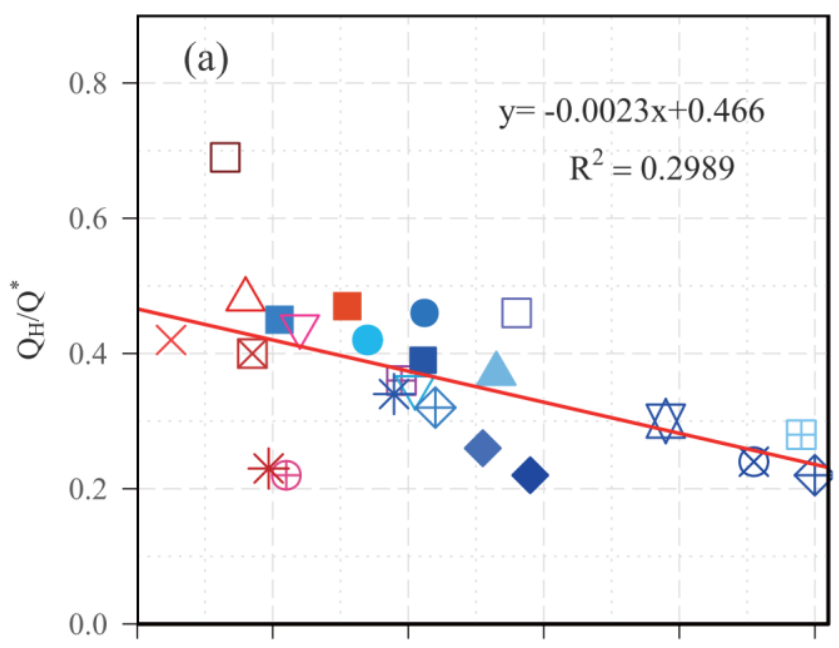

Site code
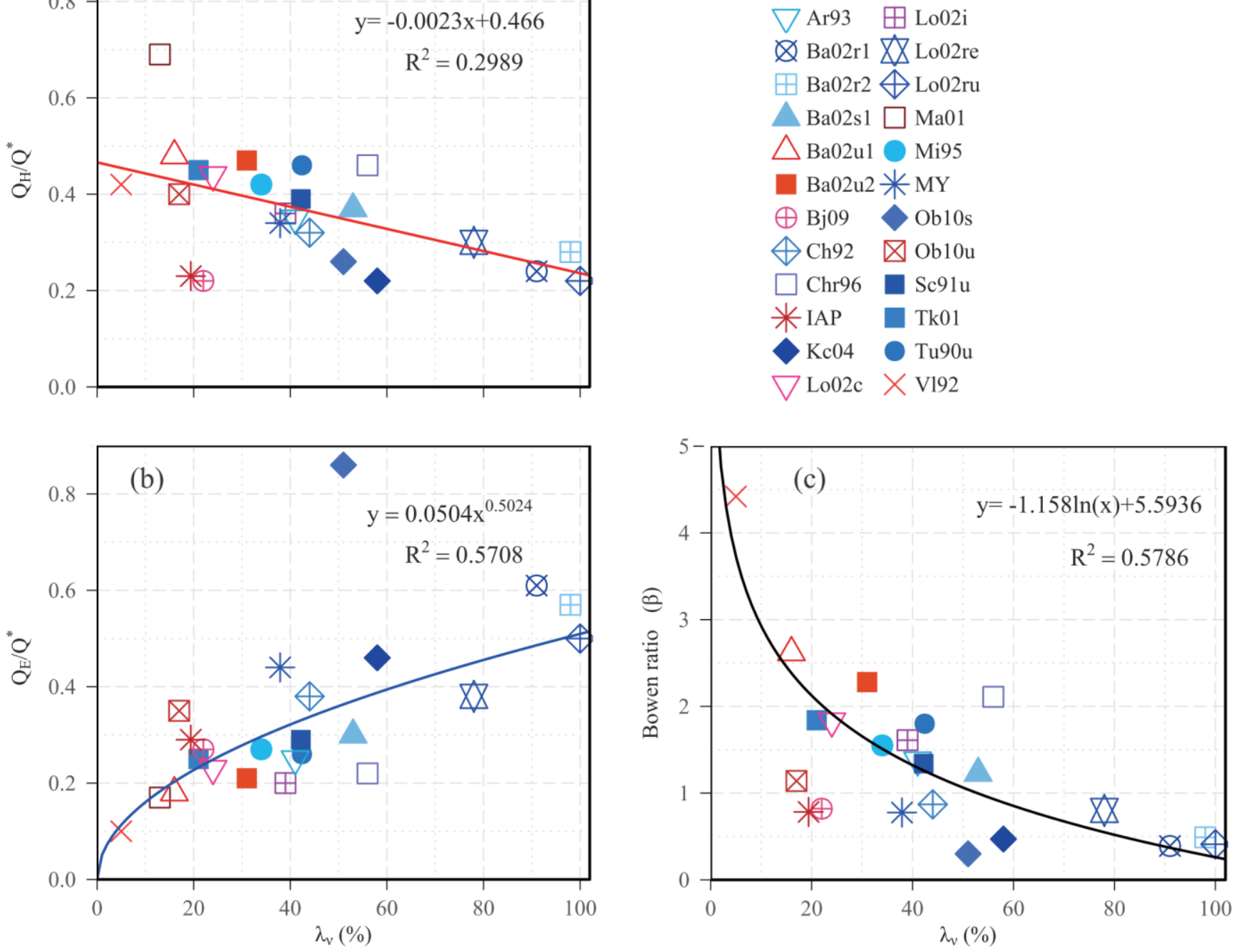
Dou JX, CSB Grimmond, Z Cheng, S Miao, D Feng, M Liao Summertime surface energy balance fluxes at two Beijing sites, International Journal of Climatology doi:10.1002/joc.5989

Figure 10. Daytime $\left(K_{\downarrow}>5 \mathrm{~W} \mathrm{~m}^{-2}\right)$ Bowen ratio (circle) and median 30 min daytime Bowen ratio (diamond) for each day (right hand axis) coloured by number of days since rainfall (days in legend). Daily rainfall amounts (bars) given on left-hand axis.

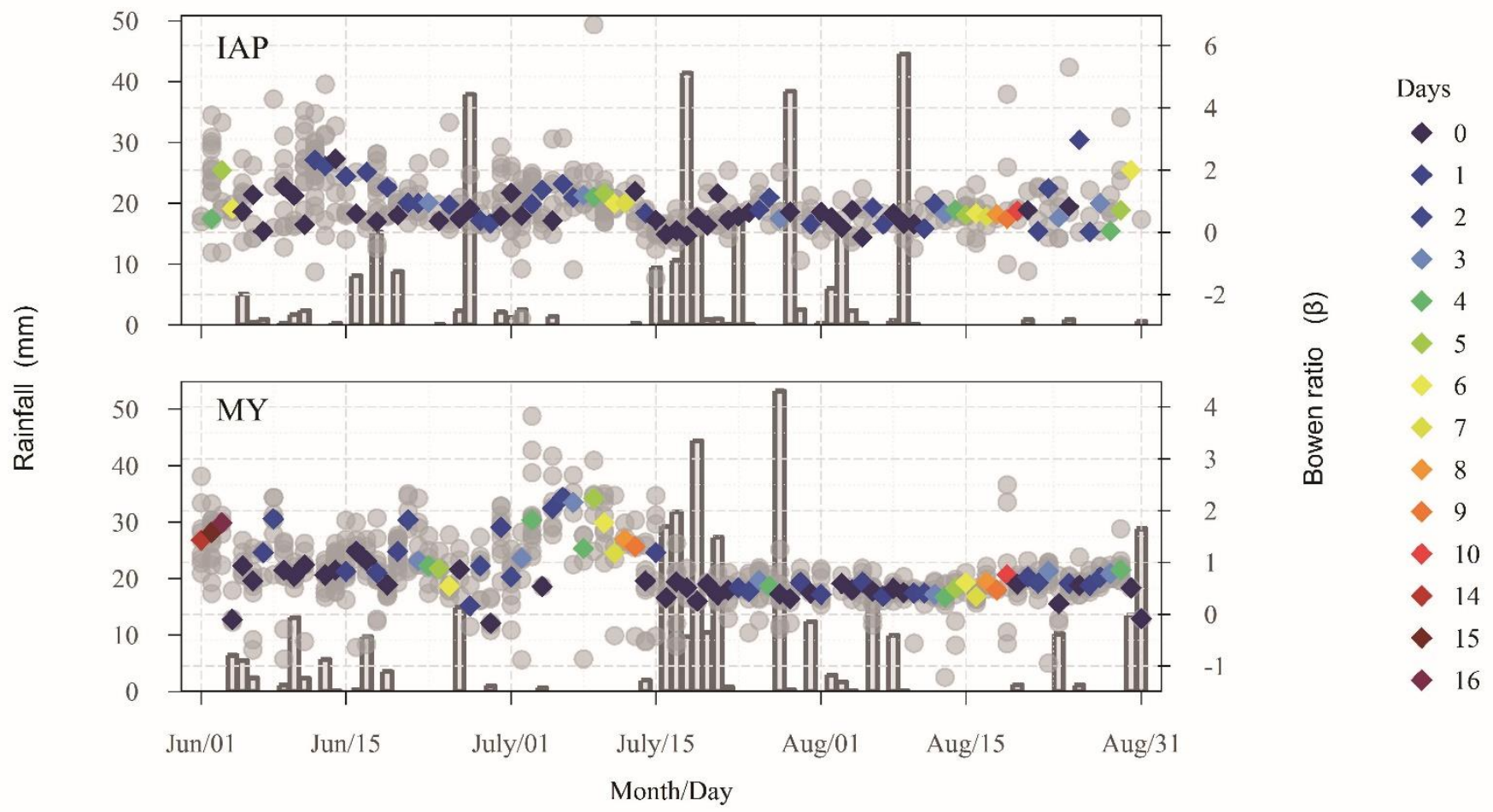

Figure 11. Bowen ratio at IAP when $K_{\downarrow}>5 \mathrm{~W} \mathrm{~m}^{-2}$ (diamond) and when $Q^{*}>500 \mathrm{~W} \mathrm{~m}^{-2}$ (circle) coloured by hours since last rainfall.

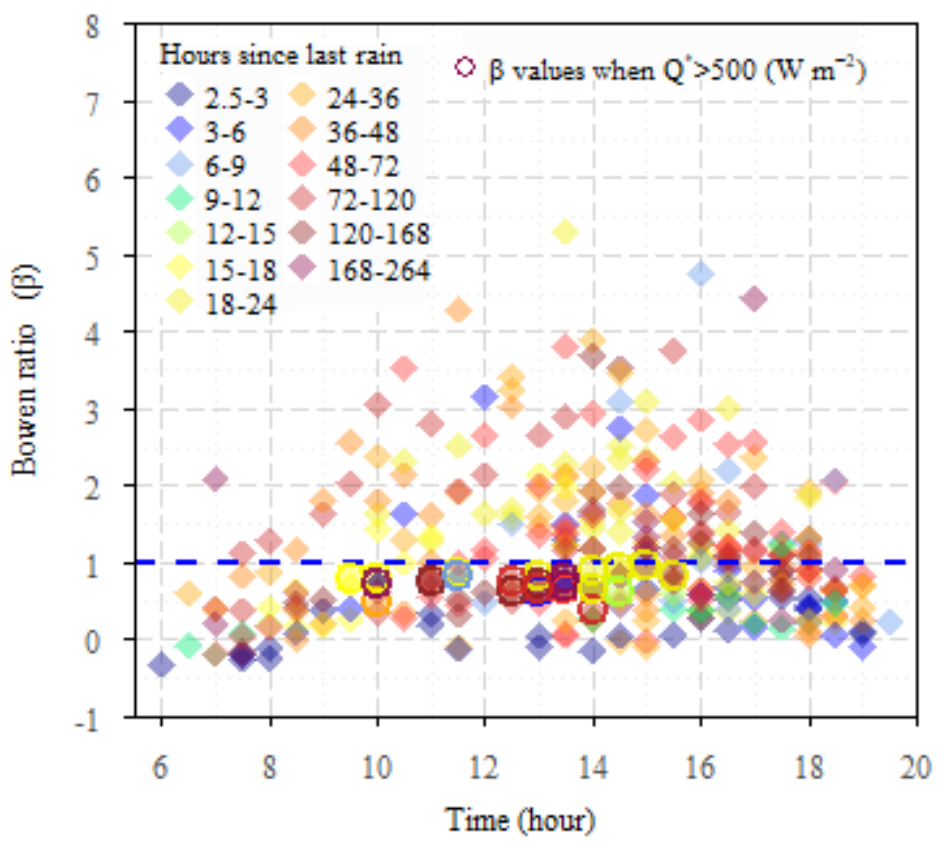


Dou JX, CSB Grimmond, Z Cheng, S Miao, D Feng, M Liao Summertime surface energy balance fluxes at two Beijing sites, International Journal of Climatology doi:10.1002/joc.5989

Figure 12. Gravimetric soil moisture (\%) measured at the MY site from 28 May to 28 August 2015 under natural and irrigated cropland.

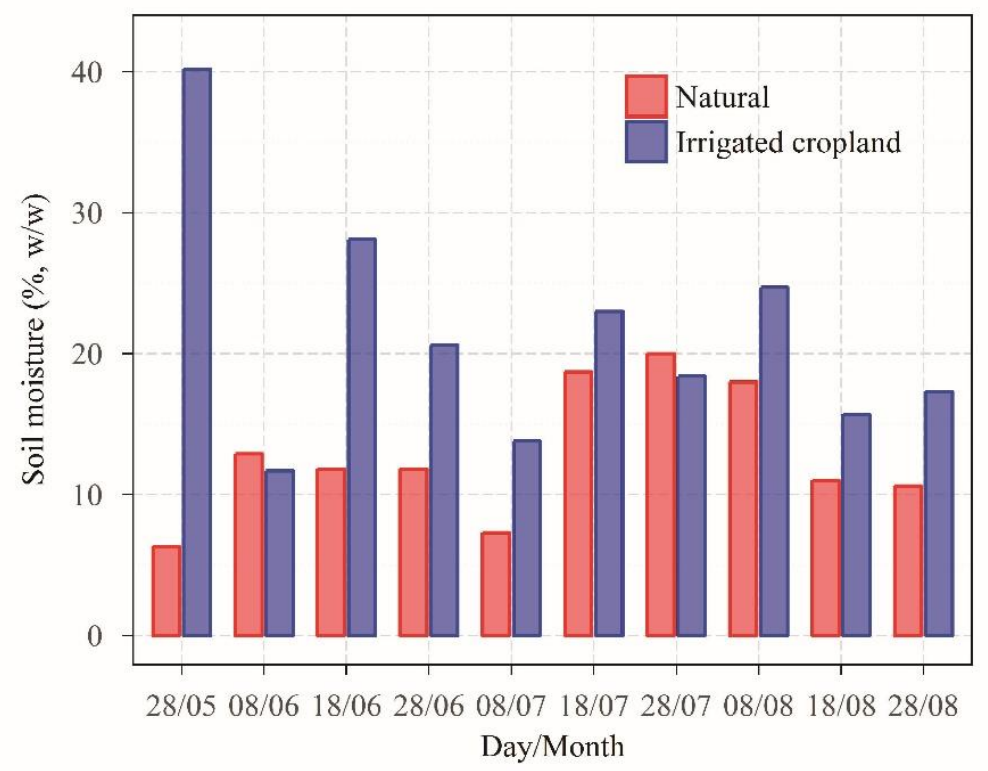

Figure 13. Wind direction and speed frequency (30 min) at MY for: (a) 5 to 13 July and (b) 9 to 18 August 2015.

(a)

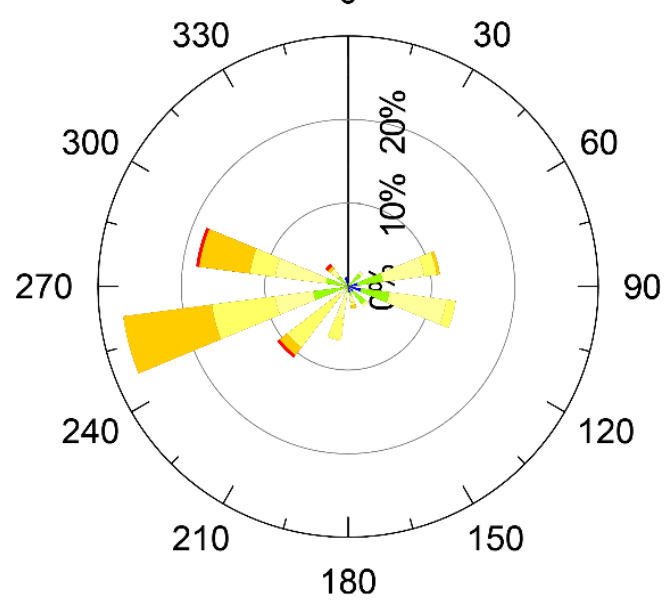

(b)

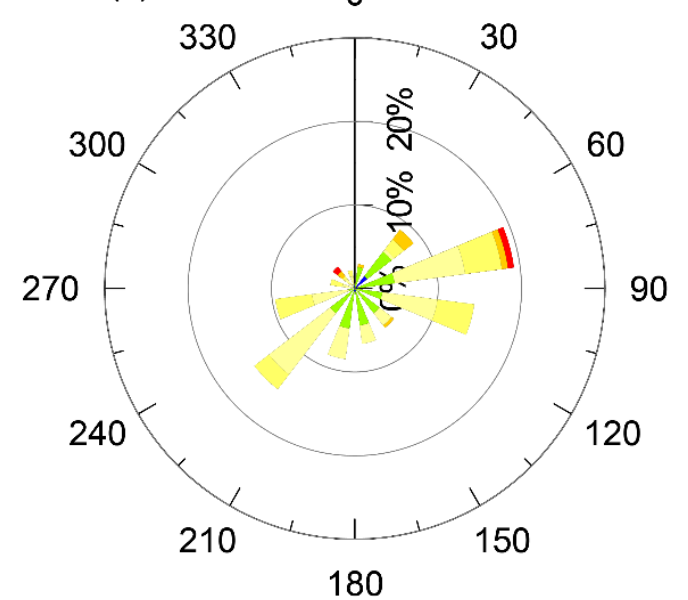

WS $\left(\mathrm{m} \mathrm{s}^{-1}\right)$

$<=0.2$

$>0.2-1$

$>1-2$

$>2-3$

$>3-4$

$>4-5$

$>5$

Figure 14. Daily 30-min midday (grey) and median Priestley-Taylor aridity parameter $\left(\alpha_{P T}\right) \quad$ (coloured by crop growth stage) at MY from 1 June to 31 August 2015.

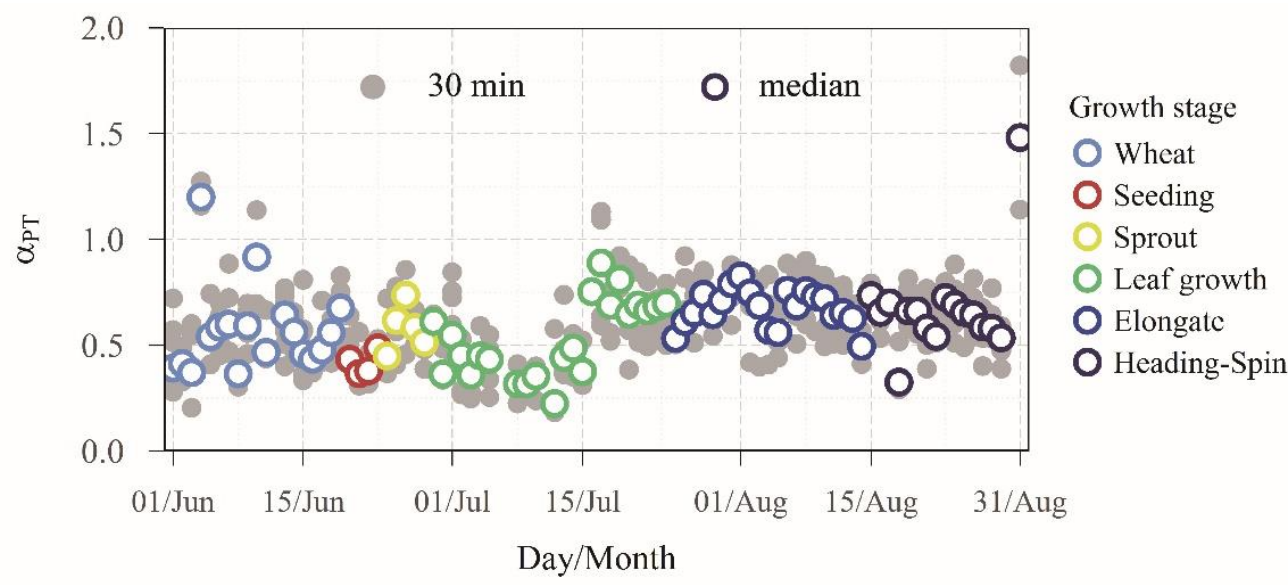


Dou JX, CSB Grimmond, Z Cheng, S Miao, D Feng, M Liao Summertime surface energy balance fluxes at two Beijing sites, International Journal of Climatology doi:10.1002/joc.5989

Table 1. Characteristics around the two study sites, sources: population density (CIESIN, 2016); * Beijing 1:2000 scale topographic map vector data (Zhang et al., 2013); ^ Survey and assessment report for weather station observational environment; \# GF-2 High-resolution image (CCRSDA, 2016); n/a - not available.

\begin{tabular}{lcc}
\hline & Urban - IAP & Suburban - MY \\
\hline Latitude $\left({ }^{\circ} \mathrm{E}\right)$, Longitude $\left({ }^{\circ} \mathrm{N}\right)$ & $116^{\circ} 22^{\prime} 15^{\prime \prime}, 39^{\circ} 58^{\prime} 28^{\prime \prime}$ & $116^{\circ} 51^{\prime} 51^{\prime \prime}, 40^{\circ} 22^{\prime} 39^{\prime \prime}$ \\
Land use & $\begin{array}{c}\text { Residential/ Commercial } \\
\text { Institutional }\end{array}$ & Government/ Residential/ Agriculture \\
Local Climate Zone (Stewart and Oke, 2012$)$ & 1,2 & 5 \\
Population density $2015\left(\right.$ people $\left.\mathrm{km}^{-2}\right)$ & 14734 & 1007 \\
Measurement height $(\mathrm{m}) z_{m}$ & 140 & 36 \\
Mean building height $(\mathrm{m}) z_{H}$ & $25.5^{*}$ & $20.4^{\wedge}$ \\
Range for $8-500 \mathrm{~m}$ radius sector s $(\mathrm{m})$ & $(6.5-46.0)$ & $8.5^{\wedge}$ \\
Average tree height $($ trees $>1.5 \mathrm{~m})(\mathrm{m}) z_{T T}$ & $\mathrm{n} / \mathrm{a}$ & $\mathrm{n} / \mathrm{a}$ \\
Canopy aspect ratio H/W & $0.39^{*}$ & $\mathrm{n} / \mathrm{a}$ \\
Range for 8 -500 m sectors & $(0.09-1.05)$ & 69.6 \\
Sky view factor $\psi_{s k y}$ & $0.722^{*}$ & 20.6 \\
Surface cover within $1 \mathrm{~km}$ radius $(\%) \#$ & & 14.6 \\
$\lambda_{I}$ Impervious & 79.8 & 34.4 \\
$\lambda_{b}$ buildings & 23.7 & 30.3 \\
$\lambda_{r}$ roads & 19.2 & 7.2 \\
$\lambda_{p}$ parking and pavement & 36.9 & 8.1 \\
$\lambda_{V}$ Vegetation & 19.6 & 15.0 \\
$\lambda_{t}$ trees & 16.1 & 0.1 \\
$\lambda_{g}$ grass & 3.5 & 0 \\
$\lambda_{f}$ farmland & 0.6 & \\
$\lambda_{W}$ Water & & \\
\hline
\end{tabular}

Table 2. Land cover of $90 \%$ source-area surface characteristics for radiometer and turbulent fluxes $(\zeta<0.1)$ centered on the measurement location. Surface cover is derived from GF-2 High-resolution image (CCRSDA, 2016).

\begin{tabular}{lcccc}
\hline & \multicolumn{2}{c}{ URBAN - IAP } & \multicolumn{2}{c}{ SUBURBAN - MY } \\
\hline Surface cover (\%) & Radiometer & Turbulent fluxes & Radiometer & Turbulent fluxes \\
\hline$\lambda_{I}$ Impervious & 71.9 & 80.0 & 48.2 & 62.0 \\
$\lambda_{b}$ buildings & 29.1 & 24.4 & 25.6 & 18.0 \\
$\lambda_{r}$ roads & 33.6 & 17.5 & 12.2 & 12.4 \\
$\lambda_{p}$ parking and pavement & 9.2 & 38.1 & 10.4 & 31.6 \\
$\lambda_{V}$ Vegetation & 25.7 & 19.4 & 51.8 & 38.0 \\
$\lambda_{t}$ trees & 11.5 & 15.8 & 15.0 & 7.0 \\
$\lambda_{a}$ grass & 14.2 & 3.6 & 30.8 & 9.7 \\
$\lambda_{f}$ farmland & 0 & 0 & 6.0 & 21.3 \\
$\lambda_{W}$ Water & 2.4 & 0.6 & 0 & 0 \\
\hline
\end{tabular}

Table 3 Mean radiation and energy fluxes, transmissivity and mean fluxes ratios normalized by net all wave radiation $\left(\mathrm{Q}^{*}\right)$ and incoming radiation $(\mathrm{Q}$ $\left.\downarrow=\mathrm{K}_{\downarrow}+\mathrm{L}_{\downarrow}\right)$ in summer 2015 for the IAP and MY sites. Where $\mathrm{K}_{\downarrow}$ and $\mathrm{K}_{\uparrow}$ are incoming and outgoing shortwave radiation; $\mathrm{L}_{\downarrow}$ and $\mathrm{L}_{\uparrow}$ are incoming and outgoing longwave radiation; $\mathrm{Q}_{\mathrm{H}}$ and $\mathrm{Q}_{\mathrm{E}}$ are turbulent sensible and latent heat fluxes; $\mathrm{Q}_{\mathrm{F}}$ is anthropogenic heat flux calculated by LQF version (Gabey et al. 2108, Lindberg et al. 2018) of the LUCY model (Allen et al., 2011; Lindberg et al., 2013); storage heat flux $Q_{\text {res }}=$ $\mathrm{Q}^{*}+\mathrm{Q}_{\mathrm{F}}-\left(\mathrm{Q}_{\mathrm{H}}+\mathrm{Q}_{\mathrm{E}}\right) ;$ Albedo $=\mathrm{K}_{\downarrow} / \mathrm{K}_{\uparrow} ; \tau$ transmissivity $=\mathrm{K}_{:} / \mathrm{G}_{0}$

\begin{tabular}{|c|c|c|c|c|c|c|c|c|c|c|c|c|c|c|c|c|c|c|c|c|}
\hline Time & Sites & $\mathbf{K}_{\downarrow}$ & $\mathbf{K}_{\uparrow}$ & $\mathbf{L}_{\downarrow}$ & $\mathbf{L}_{\uparrow}$ & $\mathbf{Q}_{\downarrow}$ & $\mathbf{Q}^{*}$ & $\mathbf{Q}_{\mathbf{H}}$ & $\mathbf{Q}_{\mathbf{E}}$ & $\mathbf{Q}_{\mathrm{F}}$ & $Q_{\text {res }}$ & Albedo & $\tau$ & $\mathbf{Q}_{\mathrm{H}} / \mathbf{Q}_{\mathrm{E}}$ & $\mathbf{Q}_{\mathrm{H}} / \mathbf{Q}^{*}$ & $\mathbf{Q}_{\mathrm{E}} / \mathbf{Q}^{*}$ & Qres/Q* & $\mathbf{Q}_{\mathrm{H}} / \mathbf{Q}_{\downarrow}$ & $\mathbf{Q}_{\mathrm{E}} / \mathbf{Q}_{\downarrow}$ & Qres/ $\mathbf{Q}_{\downarrow}$ \\
\hline Midday & IAP & 581.3 & 60.8 & 408.7 & 474.2 & 990.0 & 455.0 & 94.3 & 96.4 & 67.2 & 331.5 & 1 & 0.49 & 0.98 & 0.21 & 0.21 & 0.73 & 0.10 & 0.10 & 0.33 \\
\hline 10:00- 14:00 & MY & 605.2 & 75.7 & 418.2 & 490.7 & 1023.4 & 457.1 & 147.2 & 177.5 & 25.1 & 157.5 & 0.13 & 0.51 & 0.83 & 0.32 & 0.39 & 0.34 & 0.14 & 0.17 & 0.15 \\
\hline Daytime & IAP & 327.8 & 37.4 & 404.1 & 464.2 & 731.9 & 230.3 & 54.7 & 74.8 & 59.8 & 160.6 & 0.11 & 0.45 & 0.73 & 0.24 & 0.32 & 0.70 & 0.07 & 0.10 & 0.22 \\
\hline $\mathrm{K} \downarrow>5 \mathrm{~W} \mathrm{~m}^{-2}$ & MY & 351.7 & 45.7 & 409.7 & 472.4 & 761.4 & 243.3 & 82.9 & 115.6 & 22.3 & 67.1 & 0.13 & 0.46 & 0.72 & 0.34 & 0.48 & 0.28 & 0.11 & 0.15 & 0.09 \\
\hline Daytime & IAP & 402.6 & 44.8 & 407.7 & 468.6 & 810.3 & 296.9 & 67.3 & 85.9 & 64.2 & 207.9 & 0.11 & 0.45 & 0.78 & 0.23 & 0.29 & 0.70 & 0.08 & 0.11 & 0.26 \\
\hline $\mathbf{Q}^{*}>\mathbf{0} \mathbf{W ~ m}^{-2}$ & MY & 417.0 & 53.6 & 412.1 & 477.0 & 829.1 & 298.5 & 102.1 & 131.5 & 23.2 & 88.1 & 0.13 & 0.46 & 0.78 & 0.34 & 0.44 & 0.30 & 0.12 & 0.16 & 0.11 \\
\hline Daily & IAP & 204.3 & 23.2 & 402.0 & 456.7 & 606.2 & 126.3 & 32.0 & 56.7 & 48.1 & 85.7 & 0.11 & 0.45 & 0.56 & 0.25 & 0.45 & 0.68 & 0.05 & 0.09 & 0.14 \\
\hline $24 \mathrm{~h}$ & MY & 211.8 & 27.5 & 404.2 & 458.6 & 616.0 & 129.9 & 41.9 & 85.2 & 18.0 & 20.8 & 0.13 & 0.46 & 0.49 & 0.32 & 0.66 & 0.16 & 0.07 & 0.14 & 0.03 \\
\hline
\end{tabular}

